\title{
Therapeutic Benefits of Al-hijamah: in Light of Modern Medicine and Prophetic Medicine
}

\author{
Salah Mohamed El Sayed ${ }^{1,2, *}$, Abdel-Salam Al-quliti, ${ }^{3,4}$ Hany Salah Mahmoud ${ }^{5}$, Hussam Baghdadi ${ }^{2}$, Reham A. Maria ${ }^{2,6}$, \\ Manal Mohamed Helmy Nabo ${ }^{7,8}$, Ahmad Hefny ${ }^{5}$ \\ ${ }^{1}$ Department of Medical Biochemistry, Sohag Faculty of Medicine, Sohag University, Egypt \\ ${ }^{2}$ Department of Clinical Biochemistry and Molecular Medicine, Taibah Faculty of Medicine, Taibah University, Al-Madinah Al- \\ Munawwarah, Saudi Arabia \\ ${ }^{3}$ Alternative \& Complementary Medicine Administration, Al-Madinah Al-Munawwarah, Kingdom of Saudi Arabia \\ ${ }^{4}$ Consultant Pediatrician, Directorate of Health administration and Therapeutic Services, Al-Madinah Al-Munawwarah, Kingdom of \\ Saudi Arabia \\ ${ }^{5}$ World Federation of Alternative and Complementary Medicine, Cairo Regional Headquarter, Cairo, Egypt \\ ${ }^{6}$ Department of Medical Biochemistry, Tanta Faulty of Medicine, Tanta University, Egypt \\ ${ }^{7}$ Department of Pediatrics, Sohag Teaching Hospital, Sohag, Egypt \\ ${ }^{8}$ Division of Pediatric cardiology, Department of Pediatrics, Maternity and Children Hospital, King Abdullah Medical City, Al- \\ Madinah Al-Munawwarah, Kingdom of Saudi Arabia \\ *Corresponding author: salahfazara@yahoo.com; drsalahpediatr@yahoo.com
}

Received March 23, 2014; Revised April 26, 2014; Accepted May 03, 2014

\begin{abstract}
Excretory treatment modalities that excrete pathological substances outside human body deserve more research attention as this may potentiate the therapeutic effects of pharmacological treatments. Overcoming language barrier through translating the national medical literature to medical English to be introduced to the international medical literature is vital. Wet cupping therapy (WCT) of prophetic medicine (Al-hijamah) is practiced in the Arabic medical literature where it is reported to treat many diseases differing in etiology and pathogenesis. Al-hijamah may be referred to as bloodletting cupping therapy or blood cupping therapy in medical studies and reports from Arabic countries. Both Chinese dry cupping therapy and WCT are partial steps of Al-hijamah. In this article, we review scientific principles, methodology, indications and therapeutic benefits of Al-hijamah in comparison with acupuncture and other types of cupping therapy. Scientific and medical bases of Al-hijamah were recently reported in the evidence-based Taibah mechanism (Taibah theory) where Al-hijamah is the only excretory treatment that clears blood, lymph and intercellular fluids from causative pathological substances (CPS). Al-hijamah benefits from the histological structure of the skin in performing a percutaneous pressure-dependent and size-dependent nonspecific blood filtration and excretion of CPS through the fenestrated skin capillaries upon application of negative pressure suction using sucking cups. Al-hijamah benefits also from the production of endogenous nitric oxide (vasodilator, antineoplastic and antimicrobial agent). Al-hijamah exerts many other health benefits e.g. enhancement of immunity and pharmacological potentiation. Al-hijamah was reported to clear blood significantly from serum triglycerides, total cholesterol, LDL-cholesterol, ferritin (circulating iron stores), uric acid, autoantibodies, cytokine receptors and others. Those therapeutic benefits may treat some diseases e.g. hyperlipidemia, hypertension, atherosclerosis, coronary heart diseases, gout, musculoskeletal pain conditions, hepatitis and iron overload conditions e.g. thalassemia. Importance of Al-hijamah may increase more in modern societies due to western diets and western life style. Therapeutic benefits of Al-hijamah are mainly related to the amount of excreted CPS not the amount of letted blood. Al-hijamah may carry some advantages better than acupuncture and other types of cupping therapy in treating a large number of diseases differing in etiology and pathogenesis.
\end{abstract}

Keywords: Cupping therapy, Al-hijamah, prophetic medicine, Taibah theory, Taibah sign, causative pathological substances, indices of Al-hijamah, differential excretion phenomenon

Cite This Article: Salah Mohamed El Sayed, Abdel-Salam Al-quliti, Hany Salah Mahmoud, Baghdadi Hussam, Reham A. Maria, Manal Mohamed Helmy Nabo, and Ahmad Hefny, "Therapeutic Benefits of Al-hijamah: in Light of Modern Medicine and Prophetic Medicine.” American Journal of Medical and Biological Research, vol. 2, no. 2 (2014): 46-71. doi: 10.12691/ajmbr-2-2-3.

\section{Introduction}

In modern medicine, there is no treatment modality that can purify both blood and interstitial fluids from noxious substances that are responsible for (or resulting from) disease pathogenesis. There is no physiological mechanism to excrete excess unwanted substances in blood (and interstitial fluids) that may disturb blood chemistry and physiological homeostasis causing different 
diseases e.g. high serum iron and ferritin in conditions of iron overload (e.g. thalassemia, hemochromatosis and bronze diabetes), high serum cholesterol, triglycerides and low density lipoproteins (LDL) in hyperlipidemia and atherosclerosis, high serum uric acid in gout and high interstitial fluid urate in gouty arthritis and others. Alhijamah (cupping therapy of prophetic medicine) excretes all the above-mentioned noxious substances [1]. So, Alhijamah may carry therapeutic benefits to all the abovementioned medical conditions altogether. There is a bad need for using Al-hijamah in treating human diseases that are not responding well to current treatment modalities.

There is no pharmacological excretory treatment as all pharmacological treatments are introductory treatments needing careful study regarding possible precautions, drug-drug interactions, side effects and contraindications. However, some pharmacological treatments as iron chelation therapy may work to facilitate excretion of noxious substances e.g. excess iron in iron overload conditions. Excretory treatment modalities deserve more research attention as they may potentiate therapeutic effects of pharmacological treatments. Overcoming the language barrier through translating the national medical literature to medical English to be introduced to the international medical literature is of vital importance. Wet cupping therapy (WCT) of prophetic medicine (Alhijamah) is practiced in the Arabic medical literature and is reported to treat many diseases differing in etiology and pathogenesis.

Better therapeutic effects and patients' benefits may be gained when combining pharmacological treatments with excretory treatments e.g. cupping therapy. The need for Al-hijamah as a therapeutic modality increases more in the modern societies where the incidence of some diseases e.g. hyperlipidemia and hypertension increases. Al-hijamah may be referred to as bloodletting cupping therapy or blood cupping therapy in medical studies and reports from Arabic countries.

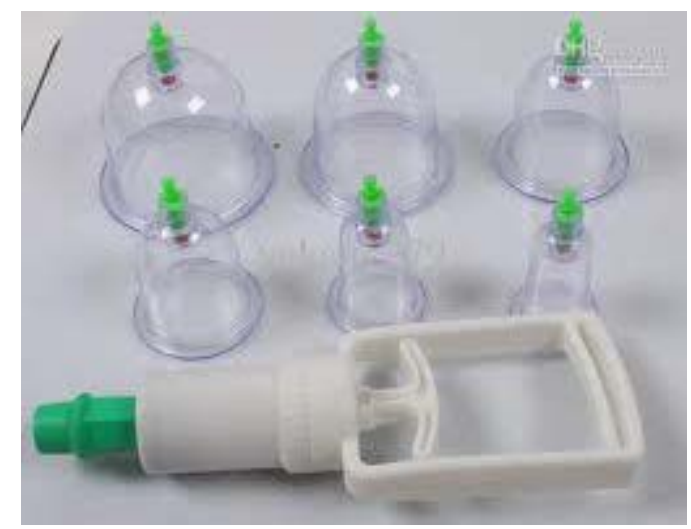

Figure 1. Disposable sterile equipment for performing Al-hijamah are so simple. Disposable variable-sized plastic cups and a manual hand-help pump

Cupping therapy is a term given to therapies using sucking cups (Figure 1) applied to certain skin areas for different therapeutic purposes. Suction applied to cups is an external factor that can be created and controlled according to the therapeutic indications [2,3]. Cupping therapy is a simple, effective, economic, time-saving and synergistic line of treatment with pharmacotherapy. Cupping therapy has a deep-rooted history that is shared by different human civilizations. Dry cupping therapy (DCT) is a one-suction step technique (single $\mathrm{S}$ technique), where cups are applied to the skin for the purpose of sucking skin into cups. Moving the cups along the skin surface is described as moving cupping therapy. Traditional wet cupping therapy (WCT) is a two-step technique that involves scarifying skin superficially followed by cupping (suction using sucking cups) i.e. double $\mathrm{S}$ technique. Al-hijamah (WCT of prophetic medicine) is a three-step technique (suction, scarification and suction technique i.e. triple $\mathrm{S}$ technique) that is unique in its historical origin (Arabic in origin) and its steps that are still practiced in Arabic and Islamic countries [2,3,4].

Prophetic medicine is a term given to the medical knowledge gained from teachings, sayings (hadeeths), advices and deeds of prophet Muhammad peace be upon him related to health and disease treatment. [5] Recently, Loukas et al. reported that medical knowledge gained from Qur'an (spoken word of God) and hadeeths (spoken word of prophet Muhammad peace be upon him) can be an important source of humanity medicine in light of their astonishing agreement with modern medical knowledge [6].

\section{Steps and Medical Bases of Al-hijamah}

Prior to performing cupping therapy (including Alhijamah), routine sterilization of the anatomical sites upon which cups will be applied must be done. Exact localization of those anatomical sites is critical to ensure success of the treatment plan. We recently reported the suitable anatomical sites for practicing Al-hijamah. [7] Sterilization is the first step and last step of cupping therapy. [3] Steps of cupping therapy differ according to the type of cupping therapy and the therapeutic indications. Single S cupping therapy (DCT) is a one-step cupping technique devoid of any excretory function i.e. only suction step with no skin scarification (Table 1). Double S cupping therapy (traditional Chinese WCT) has a single cupping (pressure-dependent filtration) step that achieves the excretory function. The step of opening the skin barrier (puncturing skin = scarification) is followed by the cupping step (Suction step = pressure-dependent excretion) i.e. double $\mathrm{S}$ technique [2,3] (Table 2). Al-hijamah combines both types of cupping therapy in a single original Arabic technique. [2,3] Triple S cupping therapy (Al-hijamah) has three steps: cupping (suction step = pressure-dependent filtration of fenestrated skin capillaries beneath skin barrier), skin scarification (= shartat mihjam = small superficial multiple short openings of the skin barrier preceded and followed by a suction step) and second cupping (second suction step = pressure-dependent filtration of fenestrated skin capillaries and pressuredependent excretion) i.e. pressure-dependent capillary filtration precedes and also follows opening the skin barrier during the triple $\mathrm{S}$ technique. [2,3] Both Chinese DCT \& WCT can be regarded as partial forms of Alhijamah. [2,3] Interestingly, the Chinese scientist Huang confirmed the difference in methodology between Chinese WCT and Arabic WCT (Al-hijamah). [4] Scientific and medical bases of Al-hijamah were recently reported in the evidence-based Taibah mechanism (Taibah theory) where Al-hijamah is an excretory form of treatment that clears blood, lymph and intercellular fluids from causative 
pathological substances (CPS) (Figure 1). [2,3] El Sayed et al. confirmed the presence of many therapeutic benefits in Al-hijamah over Chinese WCT method [2,3] (Table 2).
Al-hijamah is totally different from phlebotomy in which a pure blood loss occurs (Table 3 ).

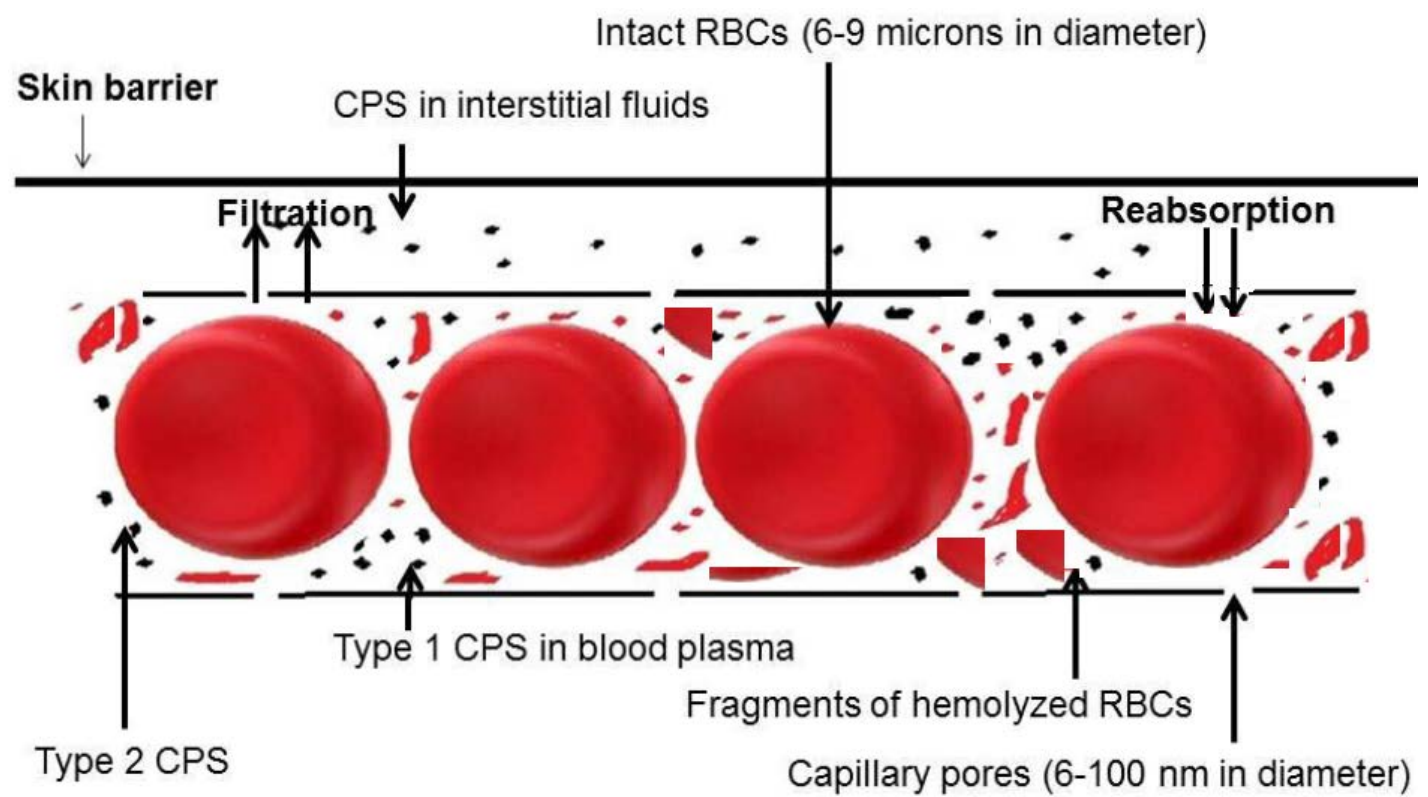

Figure 2. Disease conditions are mostly characterized by abnormal blood chemistry. Different causative pathological substances (disease-causing substances and disease-related substances) are present in the blood and interstitial fluids and cannot be excreted by physiological mechanisms e.g. excess serum iron and ferritin in thalassemia. Excretory modalities of treatment e.g. Al-hijamah help pharmacotherapy through excreting those pathological substances

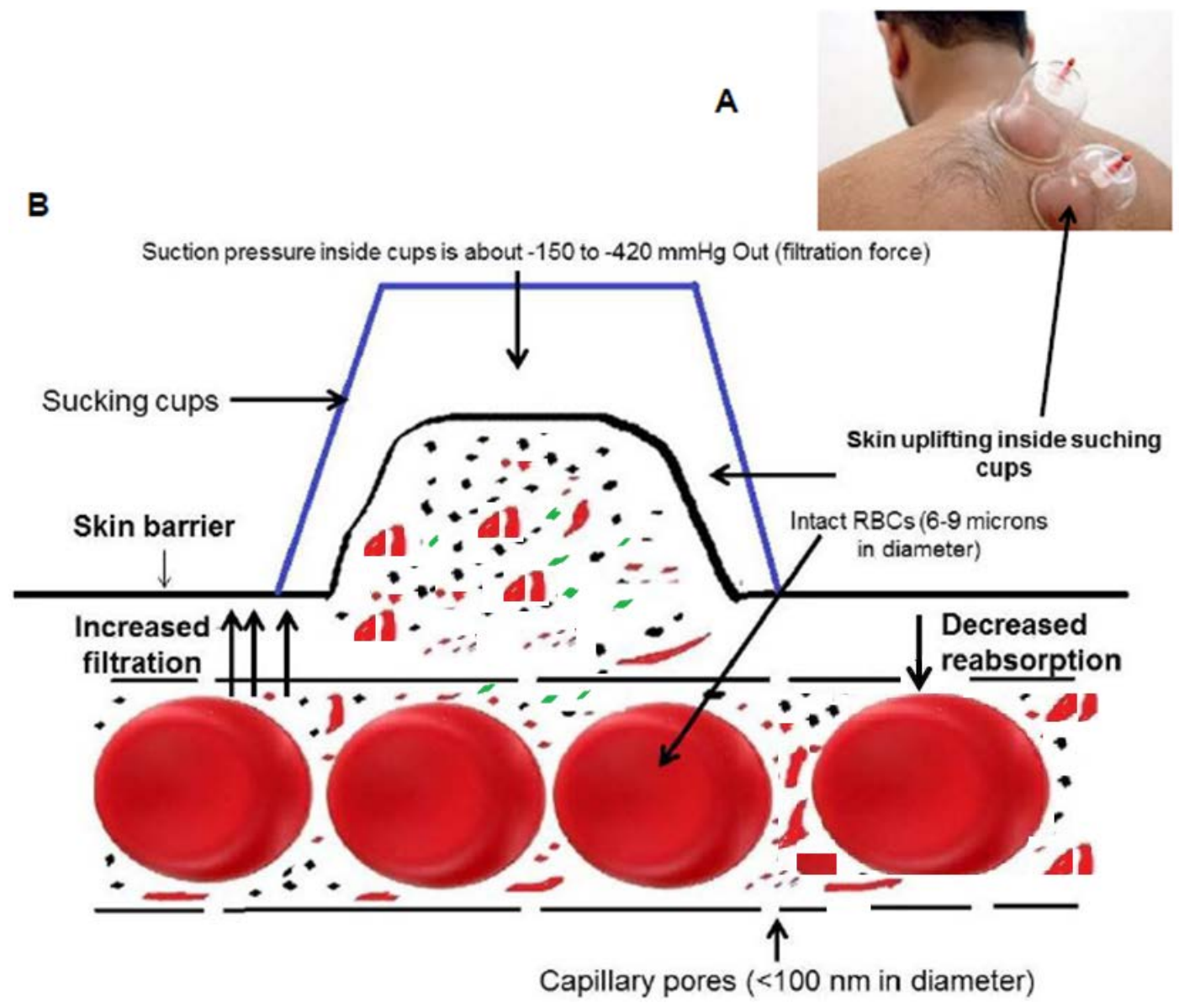

Figure 3. First technical step of Al-hijamah is first suction step. A. External negative pressure inside suction cups sucks skin into cups leading to formation of skin uplifting (skin dome). B. Inside skin uplifting, filtration of skin capillaries (pressure-dependent and size-dependent filtration and excretion) takes place. Collected fluids (filtered capillary fluids containing different causative pathological substances + collected interstitial fluids containing different causative pathological substances) start to accumulate inside the skin uplifting (skin dome) and approach the most superficial epidermal layer of the skin but cannot get out due to the presence of skin barrier. Small particles can be filtered through capillary pores and fenestrae while large particles (intact blood cells) cannot 
Table 1. Comparison between Traditional Chinese dry cupping therapy and Al-hijamah

\begin{tabular}{|c|c|c|}
\hline & Traditional Chinese dry cupping therapy & Al-hijamah \\
\hline Origin & Traditional Chinese medicine & $\begin{array}{l}\text { Arabic (Al-hijamah is wet cupping therapy of prophetic } \\
\text { medicine) }\end{array}$ \\
\hline Practiced mainly in & China, Korea, Europe and worldwide & $\begin{array}{l}\text { Arabic countries, Islamic countries and in many parts of the } \\
\text { world }\end{array}$ \\
\hline Strict sterilization & $\begin{array}{l}\text { Done at the beginning and at the end of the procedure } \\
\text { with total aseptic technique during the whole } \\
\text { procedure }\end{array}$ & Same \\
\hline Methodology & Single suction step & $\begin{array}{l}\text { - Site selection of anatomical sites for cups application } \\
\text { - Strict sterilization (at the beginning) } \\
\text { - Skin suction } \\
\text { - Scarification } \\
\text { - Skin suction } \\
\text { - Strict sterilization (at the end) }\end{array}$ \\
\hline $\begin{array}{l}\text { Excretory function of } \\
\text { disease-causing substances }\end{array}$ & Absent & Present \\
\hline Blood clearance & Absent & Present \\
\hline Therapeutic indications & $\begin{array}{l}\text { Treats mainly pain conditions and disease indications } \\
\text { that do not necessitate excretory functions e.g. } \\
\text { congestion and ischemia }\end{array}$ & $\begin{array}{l}\text { - Musculoskeletal pain conditions } \\
\text { - Hematological conditions e.g. hemolysis and iron } \\
\text { overload } \\
\text { - Cardiovascular diseases e.g. hypertension } \\
\text { - Inborn errors of metabolism e.g. galactosemia } \\
\text { - Some dermatological conditions e.g. urticaria } \\
\text { - Neuropsychiatric diseases e.g. headache } \\
\text { - Malignancy } \\
\text { - Metabolic conditions e.g. gout } \\
\text { - Infections e.g. viral hepatitis } \\
\text { - Respiratory and ENT diseases e.g. asthma } \\
\text { - Autoimmune diseases e.g. rheumatoid arthritis } \\
\text { - Gastrointestinal diseases e.g. irritable bowel syndrome } \\
\text { - Heavy metal intoxication } \\
\text { - Drug overdosage }\end{array}$ \\
\hline Therapeutic benefits & Fulfill some therapeutic benefits of Al-hijamah & Fulfill all the therapeutic benefits of Al-hijamah \\
\hline $\begin{array}{l}\text { Skin scarifications (shartat } \\
\text { mihjam is preceded and } \\
\text { followed by a suction step) } \\
\text { (Figure 5) }\end{array}$ & Absent & Present \\
\hline Therapeutic effects & $\begin{array}{l}\text { Palliative (causative pathological substances are not } \\
\text { excreted) }\end{array}$ & $\begin{array}{l}\text { Curative or may carry marked clinical improvement } \\
\text { (causative pathological substances are significantly } \\
\text { excreted) }\end{array}$ \\
\hline Side effects & $\begin{array}{l}\text { Skin bruises, ecchymosis, bullae, bluish discoloration } \\
\text { of the skin, skin hemorrhage and others } \\
\text { Are mainly caused by increased negative suction } \\
\text { pressure or suction duration. }\end{array}$ & $\begin{array}{l}\text { Few side effects are attributed to Al-hijamah e.g. Taibah } \\
\text { sign (Figure 4). There is almost no side effect when Al- } \\
\text { hijamah is practiced properly. } \\
\text { Reported side effects are mainly related to malpractice e.g. } \\
\text { prolonged suction time ( }>10 \text { minutes) and excessive } \\
\text { suction pressure ( }>-300 \mathrm{mmHg} \text { ) in dry cupping therapy or } \\
\text { deep scarifications (more than } 0.5 \mathrm{~mm} \text { in depth) in wet } \\
\text { cupping therapy. } \\
\text { Reported minor side effects of cupping therapy are keloid } \\
\text { scarring, burns and bullae [84] } \\
\text { Serious side effects are very rare and were reported to be } \\
\text { due to traditional WCT e.g. acquired hemophilia A, stroke } \\
\text { following cupping on the back and neck, factitious } \\
\text { panniculitis, reversible cardiac hypertrophy, and iron } \\
\text { deficiency anemia [84]. }\end{array}$ \\
\hline As a prophetic medicine & No & Yes \\
\hline Pharmacological potentiation & No & Yes \\
\hline $\begin{array}{l}\text { Examples of diseases treated } \\
\text { by it }\end{array}$ & Pain conditions e.g. knee osteoarthritis & A diverse number of diseases (Table 4) \\
\hline $\begin{array}{l}\begin{array}{l}\text { Mechanism of analgesic } \\
\text { benefit }\end{array} \\
\text { ben }\end{array}$ & $\begin{array}{l}\text { Dilution and redistribution of noxious soluble } \\
\text { substances may occur away from pain receptors and } \\
\text { pain-sensitive structures. }\end{array}$ & $\begin{array}{l}\text { Through excretion of fluids and excretion of wastes after } \\
\text { being diluted and redistributed in collected fluids inside } \\
\text { skin uplifting }\end{array}$ \\
\hline Suction step & $\begin{array}{l}\text { Should be less than } 5 \text { minutes done at moderate } \\
\text { suction pressure }(<-300 \mathrm{mmHg}) \text { i.e. to avoid } \\
\text { production of ecchymosis or cutaneous hemorrhage }\end{array}$ & $\begin{array}{l}\text { Usually less than } 5 \text { minutes done at moderate suction } \\
\text { pressure i.e. does not produce ecchymosis or cutaneous } \\
\text { hemorrhage }\end{array}$ \\
\hline May be regarded as & Partial form (1 $1^{\text {st }}$ third) of Al-hijamah & Complete form of Al-hijamah \\
\hline Other names & Retained cupping therapy & $\begin{array}{l}\text { Cupping, puncturing and cupping method, triple S method, } \\
\text { cupping therapy of prophetic medicine }\end{array}$ \\
\hline
\end{tabular}


Table 2. Differences between Al-hijamah and traditional wet cupping therapy

\begin{tabular}{|c|c|c|}
\hline & Traditional Chinese wet cupping therapy & Al-hijamah \\
\hline Origin & Traditional Chinese medicine & $\begin{array}{l}\text { Arabic (Al-hijamah is wet cupping therapy of prophetic } \\
\text { medicine) }\end{array}$ \\
\hline Practiced mainly in & China, Korea, Europe and worldwide & $\begin{array}{l}\text { Arabic countries, Islamic countries and in many parts of the } \\
\text { world }\end{array}$ \\
\hline Methodology & $\begin{array}{l}\text { Double S technique (skin scarification is } \\
\text { followed by suction) }\end{array}$ & $\begin{array}{l}\text { - Site selection of anatomical sites for cups application } \\
\text { - Strict sterilization (at the beginning) } \\
\text { - Skin suction } \\
\text { - Scarification } \\
\text { - Skin suction } \\
\text { - Strict sterilization (at the end) }\end{array}$ \\
\hline $\begin{array}{l}\text { Skin condition at time of } \\
\text { scarification }\end{array}$ & $\begin{array}{l}\text { Scarification is done at the skin directly. Skin } \\
\text { scarification is painful. No hypothetic or } \\
\text { anesthetic effect due to lack of 1st suction step. }\end{array}$ & $\begin{array}{l}\text { Scarifications are confined to the skin of skin uplifting beneath } \\
\text { which collected and filtered fluids exist (hypothetic or } \\
\text { anesthetic effect) }\end{array}$ \\
\hline Pain during scarification & Moderate to severe (as in wounding intact skin) & Non, mild or moderate \\
\hline Strict sterilization & $\begin{array}{l}\text { Done at the beginning and at the end of the } \\
\text { procedure with total aseptic technique during the } \\
\text { whole procedure }\end{array}$ & Same \\
\hline Blood clearance & Less & More \\
\hline $\begin{array}{l}\text { Skin scarifications (shartat } \\
\text { mihjam preceded and } \\
\text { followed by a suction step) } \\
\text { (Figure 5) }\end{array}$ & $\begin{array}{l}\text { Absent. Skin scarification in traditional WCT is } \\
\text { not preceded by a suction step. }\end{array}$ & Present \\
\hline $\begin{array}{l}\text { Fluid barrier (collected } \\
\text { beneath skin surface during } \\
1^{\text {st }} \text { suction step) }\end{array}$ & Absent (due to absence of $1^{\text {st }}$ suction step) & Present (Figure 3) \\
\hline $\begin{array}{l}\text { Possibility of injuring dermal } \\
\text { capillaries with superficial } \\
\text { scarifications }(0.1-0.2 \mathrm{~mm})\end{array}$ & $\begin{array}{l}\text { Maximal (sub-epidermal superficial capillary } \\
\text { networks are very near to the skin surface due to } \\
\text { the absence of fluid barrier) }\end{array}$ & $\begin{array}{l}\text { Minimal (sub-epidermal superficial capillary networks are } \\
\text { separated from skin surface by the presence of fluid barrier) } \\
\text { (Figure 5B) }\end{array}$ \\
\hline $\begin{array}{l}\text { Fluid-barrier induced } \\
\text { breaking of tissue adhesions }\end{array}$ & Less & More \\
\hline $\begin{array}{l}\text { Number of pressure- } \\
\text { dependent filtration steps } \\
\text { (cupping steps) }\end{array}$ & Once & Twice \\
\hline $\begin{array}{l}\text { Total time of pressure- } \\
\text { dependent filtration steps } \\
\text { (cupping steps) }\end{array}$ & $\begin{array}{l}\text { Shorter (causes less capillary filtration and blood } \\
\text { clearance) }\end{array}$ & Longer (causes more capillary filtration and blood clearance) \\
\hline $\begin{array}{l}\text { Therapeutic indications } \\
\text { treated by Al-hijamah (Table } \\
\text { 4) }\end{array}$ & $\begin{array}{l}\text { Treats most of disease indications that benefit } \\
\text { from cupping therapy }\end{array}$ & $\begin{array}{l}\text { Treats all disease indications that benefit from cupping therapy } \\
\text { - Musculoskeletal pain conditions } \\
\text { - Hematological conditions e.g. hemolysis and iron overload } \\
\text { - Cardiovascular diseases e.g. hypertension } \\
\text { - Inborn errors of metabolism e.g. galactosemia } \\
\text { - Some dermatological conditions e.g. urticaria } \\
\text { - Neuropsychiatric diseases e.g. headache } \\
\text { - Malignancy } \\
\text { - Metabolic conditions e.g. gout } \\
\text { - Infections e.g. viral hepatitis } \\
\text { - Respiratory and ENT diseases e.g. asthma } \\
\text { - Autoimmune diseases e.g. rheumatoid arthritis } \\
\text { - Gastrointestinal diseases e.g. irritable bowel syndrome } \\
\text { - Heavy metal intoxication } \\
\text { - Drug overdosage }\end{array}$ \\
\hline Therapeutic benefits & $\begin{array}{l}\text { Fulfills some therapeutic benefits of Al-hijamah } \\
\text { (Table 4) }\end{array}$ & Fulfills all therapeutic benefits of Al-hijamah (Table 4) \\
\hline $\begin{array}{l}\text { Blood clearance versus } \\
\text { bloodletting }\end{array}$ & More bloodletting and less blood clearance & More blood clearance and less bloodletting \\
\hline Side effects & $\begin{array}{l}\text { Reported minor side effects of cupping therapy } \\
\text { are keloid scarring, burns, and bullae [84] } \\
\text { Serious side effects are very rare e.g. acquired } \\
\text { hemophilia A, stroke following cupping on the } \\
\text { back and neck, factitious panniculitis, reversible } \\
\text { cardiac hypertrophy, and iron deficiency anemia } \\
\text { [84]. }\end{array}$ & $\begin{array}{l}\text { Few side effects are attributed to Al-hijamah e.g. Taibah sign } \\
\text { (Figure 4). There is almost no side effect when Al-hijamah is } \\
\text { practiced properly. } \\
\text { Reported side effects are mainly related to malpractice e.g. } \\
\text { prolonged suction time }(>10 \text { minutes) and excessive suction } \\
\text { pressure ( }>-300 \mathrm{mmHg} \text { ) in dry cupping therapy or deep } \\
\text { scarifications (more than } 0.5 \mathrm{~mm} \text { in depth) in wet cupping } \\
\text { therapy. }\end{array}$ \\
\hline Other names & $\begin{array}{l}\text { Puncturing and cupping method of wet cupping } \\
\text { therapy, double S technique }\end{array}$ & $\begin{array}{l}\text { Cupping, puncturing and cupping method, triple S method, } \\
\text { cupping therapy of prophetic medicine }\end{array}$ \\
\hline
\end{tabular}


Table 3. Comparison between Al-hijamah and phlebotomy (fasd)

\begin{tabular}{|c|c|c|}
\hline & Phlebotomy = fasd in Arabic & Al-hijamah \\
\hline Definition & $\begin{array}{l}\text { Venesection, a procedure for } \\
\text { cutting a vein to bleed to decrease } \\
\text { blood content or substances present } \\
\text { in blood inside the vessel wall }\end{array}$ & $\begin{array}{l}\text { A percutaneous minor therapeutic procedure through which pressure-dependent and } \\
\text { size-dependent non-specific filtration of the blood occurs through the fenestrated } \\
\text { dermal skin capillaries. The excretory function is done through clearance of blood } \\
\text { and interstitial fluids from causative pathological substances that differ from disease } \\
\text { to disease according to disease etiology and pathogenesis }[2,3] \text {. }\end{array}$ \\
\hline indications & $\begin{array}{l}\text { To decrease a blood component or } \\
\text { content e.g. red cell mass and } \\
\text { hematocrit value in polycythemia } \\
\text { and to decrease iron overload in } \\
\text { thalassemia }\end{array}$ & $\begin{array}{l}\text { Treats all disease indications that benefit from cupping therapy } \\
\text { - Msculoskeletal pain conditions } \\
\text { - Hematological conditions e.g. hemolysis and iron overload } \\
\text { - Cardiovascular diseases e.g. hypertension } \\
\text { - Inborn errors of metabolism e.g. galactosemia } \\
\text { - Some dermatological conditions e.g. urticaria } \\
\text { - Neuropsychiatric diseases e.g. headache } \\
\text { - Malignancy } \\
\text { - Metabolic conditions e.g. gout } \\
\text { - Infections e.g. viral hepatitis } \\
\text { - Respiratory and ENT diseases e.g. asthma } \\
\text { - Autoimmune diseases e.g. rheumatoid arthritis } \\
\text { - Gastrointestinal diseases e.g. irritable bowel syndrome } \\
\text { - Heavy metal intoxication } \\
\text { - Drug overdosage }\end{array}$ \\
\hline Methodology & $\begin{array}{l}\text { Venesection and withdrawing a } \\
\text { blood unit in a blood donation bag }\end{array}$ & $\begin{array}{l}\text { - Site selection of anatomical sites for cups application } \\
\text { - Strict sterilization (at the beginning) } \\
\text { - Skin suction } \\
\text { - Scarification } \\
\text { - Skin suction } \\
\text { - Strict sterilization (at the end) }\end{array}$ \\
\hline Side effects & Anemia, bleeding, phlebitis & Taibah sign, post-cupping sign, skin bruises \\
\hline Removal of & $\begin{array}{l}\text { Whole blood containing the } \\
\text { noxious substance to be removed }\end{array}$ & $\begin{array}{l}\text { A bloody fluid mixture (few blood cells }+ \text { hemolyzed blood cells }+ \text { filtered fluids }+ \\
\text { collected interstitial fluids }+ \text { causative pathological substances }\end{array}$ \\
\hline $\begin{array}{l}\text { Requirement for } \\
\text { subsequent } \\
\text { transfusion }\end{array}$ & Increases & Non \\
\hline repeatability & $\begin{array}{l}\begin{array}{l}\text { Repeatable if no anemia may } \\
\text { develop }\end{array} \\
\end{array}$ & Cupping bloodletting, triple S technique, prophetic Al-hijamah \\
\hline Analgesic effect & Non & Present \\
\hline $\begin{array}{l}\text { Therapeutic benefits } \\
\text { and improving } \\
\text { respiration for } \\
\text { treating smoking }\end{array}$ & Moderate [92] & Better [92] \\
\hline Other names & Bloodletting, phlebotomy, fasd & Cupping bloodletting \\
\hline
\end{tabular}

A

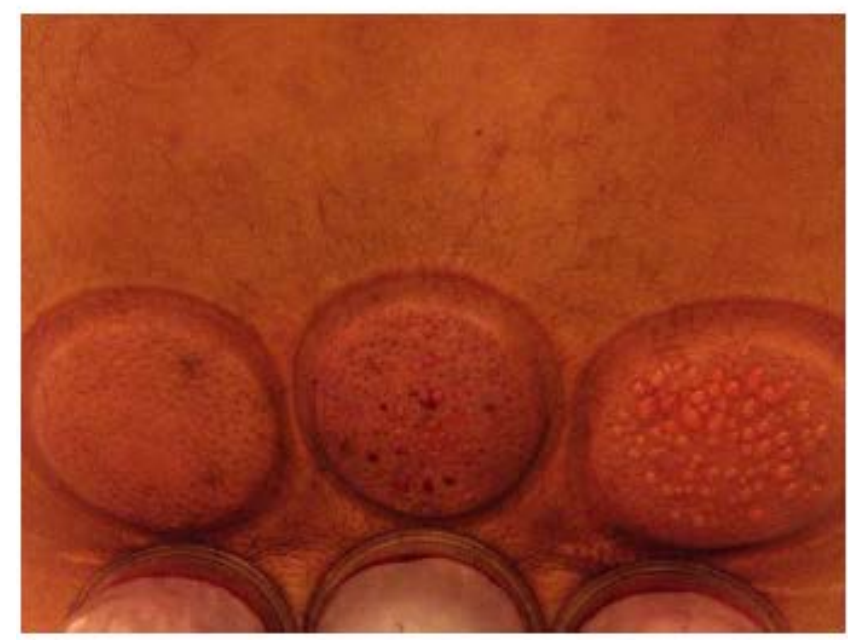

B

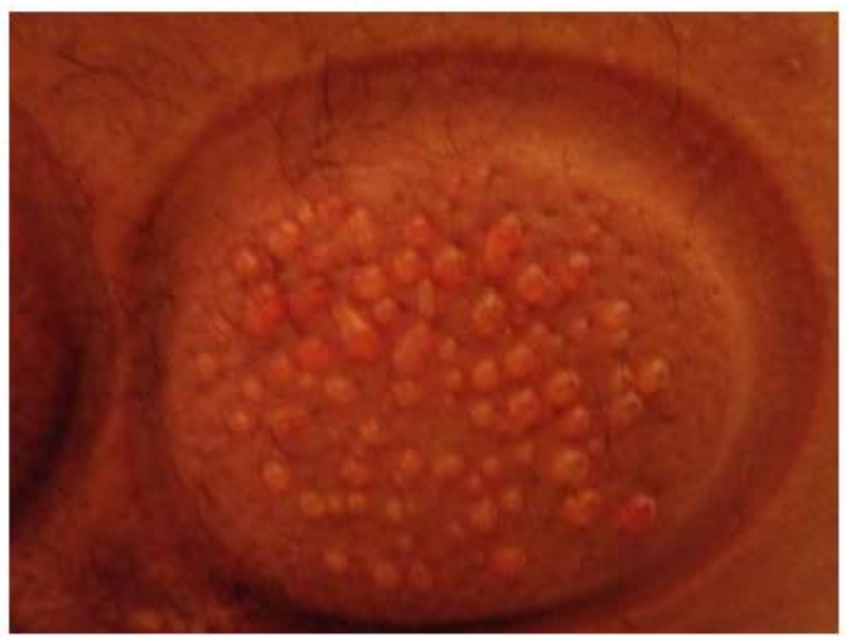

Figure 4. Taibah sign (A and B): At weak skin points of the skin uplifting (skin dome), skin vesicles (skin sacs filled with fluids) created by suction pressure may protrude through those weak skin points. Vesicles are filled with clear fluid (no blood cells as evidenced by absence of red color). Fluid inside vesicles is a fluid mixture (filtered fluid + collected interstitial fluids + CPS). Vesicles may result from increased suction pressure and or suction duration. Vesicles should be punctured using the sharp tip of a sterile scalpel. Application of local antibiotics or honey is recommended to promote healing in a sterile environment. Taibah sign is novel sign confirming Taibah mechanism for scientific bases of Al-hijamah (Taibah theory, named after Taibah city, Al-Madinah Al-Munawwarah in Saudi Arabia) 


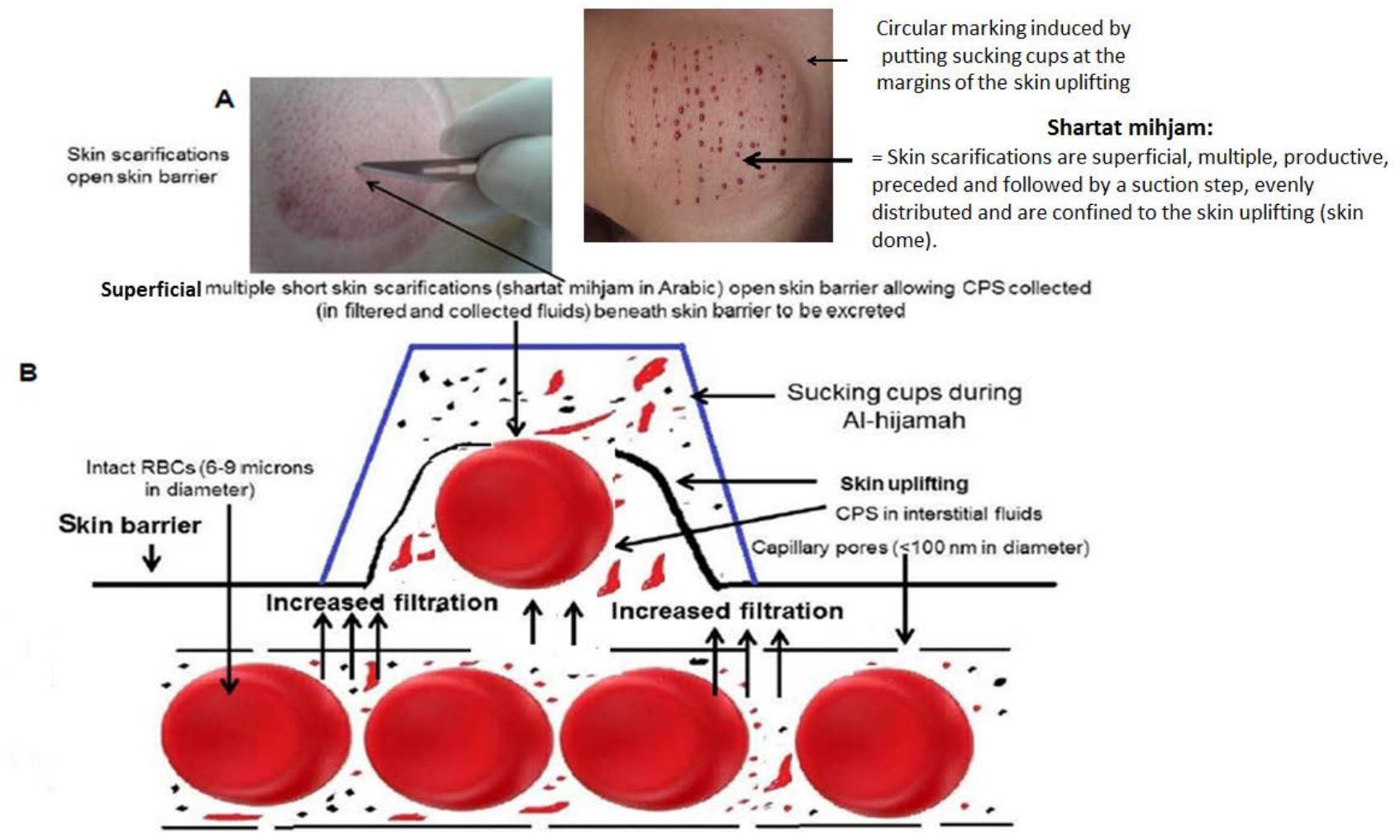

Figure 5. Second technical step in Al-hijamah is skin scarification (shartat mihjam) while third technical step is second suction. A. Skin scarifications (in Arabic: shartat mihjam) are small short superficial skin incisions (1-2 $\mathrm{mm}$ in length and $0.1 \mathrm{~mm}$ in depth). B. Skin scarifications open skin barrier for the excretion of collected fluids inside the skin uplifting (skin dome). Skin scarifications help transmission of second suction pressure to the inside of the skin uplifting (skin dome) to excrete collected fluids. Skin scarifications help transmission of second suction pressure to the inside of the skin uplifting around skin capillaries for more percutaneous capillary blood filtration. Skin scarifications cause a minor bleeding and loss of blood cells through the induced superficial skin incisions (scarifications). C. Criteria of shartat mihjam

A

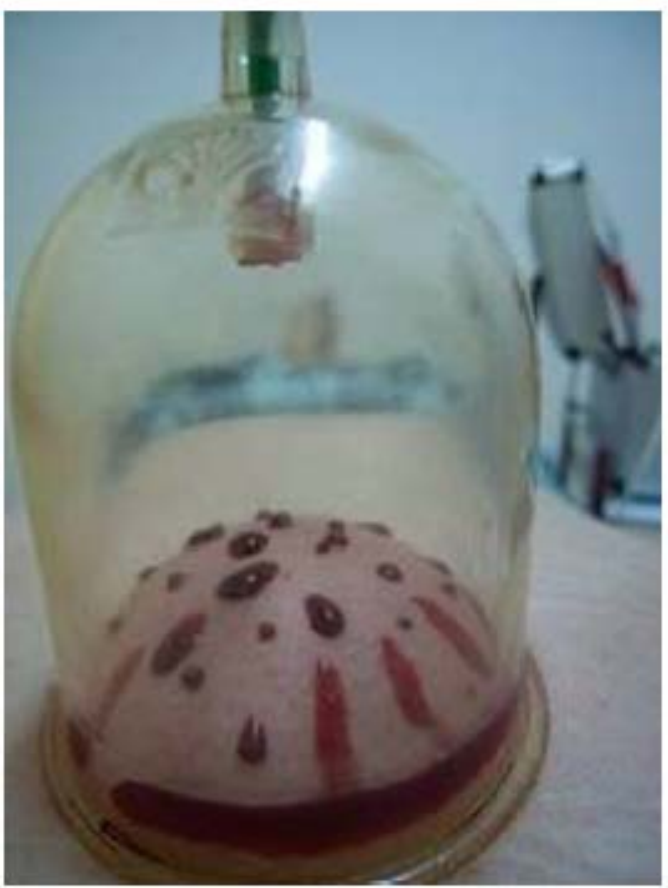

B

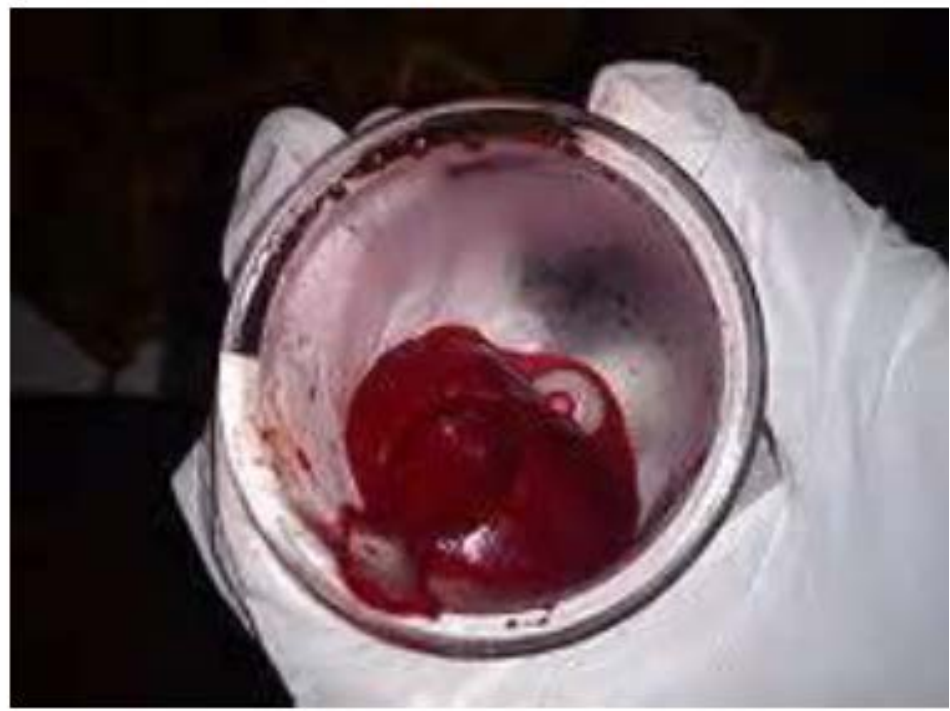

Figure 6. Excretory function of Al-hijamah. A. Excretion of a bloody fluid mixture through the skin scarification sites inside the sucking cups. B. The excreted bloody fluid through skin scarification sites coagulates rapidly inside the sucking cups

Immediately after the first step in Al-hijamah, a fluid mixture (fluid barrier) is collected inside the skin uplifting (skin dome) between the superficial epidermal layers and dermal capillaries (Figure 3). This fluid mixture includes collected interstitial fluids, lymph, filtered capillary fluids with their CPS content. The collected fluids may protrude through weak skin points forming vesicles (Taibah sign) (Figure 4). All that will be excreted immediately upon skin scarification and second cupping (Figure 5), which causes a minor bleeding and loss of blood cells through 
the induced superficial skin incisions (scarifications). Cupped bloody fluid mixture starts to coagulate rapidly during putting cups for second suction (Figure 6). Immediately after finishing the cupping session, homeostasis is restored after clearance of blood and interstitial spaces from disease CPS (Figure 7). A transient post-cupping sign exists for few days and disappears without any sequelae (Figure 8). The negative pressure applied at the skin surface during cupping therapy is variable in strength according to the method of production of this negative pressure. Huber et al. reported that large pressure differences could be obtained when using different methods for inducing negative pressure. Huber et al. reported that the mean pressure produced was $-200 \pm$ 30 hecta Pascal $(\mathrm{hPa})$ when using $2 \mathrm{~cm}$ flame, $-310 \pm 30$ hPa with $4 \mathrm{~cm}$ flame, $-560 \pm 30 \mathrm{hPa}$ with burning alcohol soaked cotton swab and $-270 \pm 16 \mathrm{hPa}$ with rubber balloon. The pressure produced through rubber balloon was the easiest technically, moderate (not too high or too low) and was the most reproducible on repeating cupping practice as evidenced by reduction of the standard deviation by a factor of 2 compared to the flame methods [8]. The most superficial skin capillaries are fenestrated [9] (capillary pore size is 6-12 $\mathrm{nm}$ and fenestral size is about 60-80 nm) [10] allowing for capillary blood filtration when external suction pressure is applied (e.g. during Alhijamah). As blood is a fluid composed of plasma (containing soluble constituents and CPS) and blood cells, suction pressure will filter small constituents (fluid and CPS having diameters in $\mathrm{nm}$ ) not larger ones (cells having diameters in microns). When small skin scarifications (1-2 $\mathrm{mm}$ ) are induced in skin barrier at skin uplifting during Al-hijamah, suction pressure will excrete collected fluids and filter smaller constituents (fluid and CPS) rather than larger ones (cells) i.e. there is a differential size-dependent filtration and excretion phenomenon (differential excretion phenomenon) occurring during Al-hijamah. Also, the rate of excretion is size-dependent i.e. smaller particles are excreted more rapidly than larger particles.

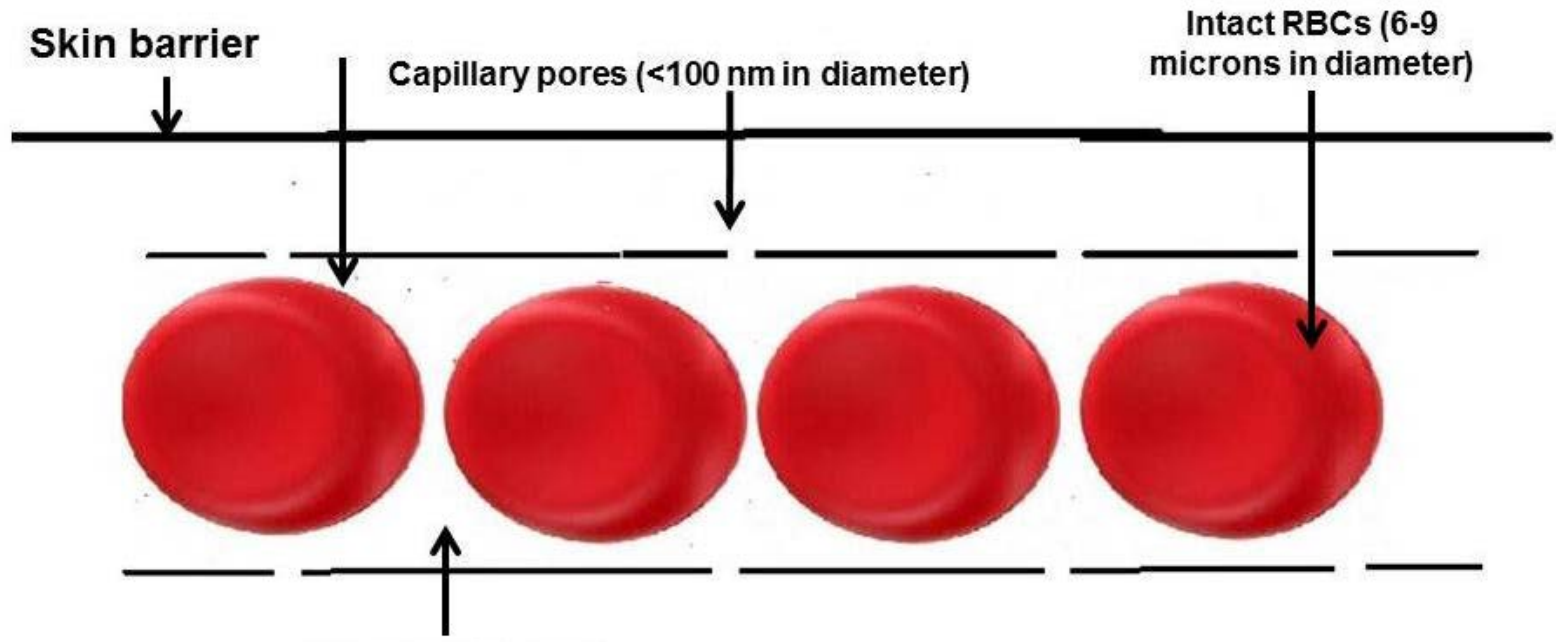

\section{No or little CPS}

Figure 7. Restoration of homeostasis after complete or partial significant excretion of disease CPS. New interstitial fluid is formed by filtration at the arterial ends of capillaries and is reabsorbed at the venous capillary ends

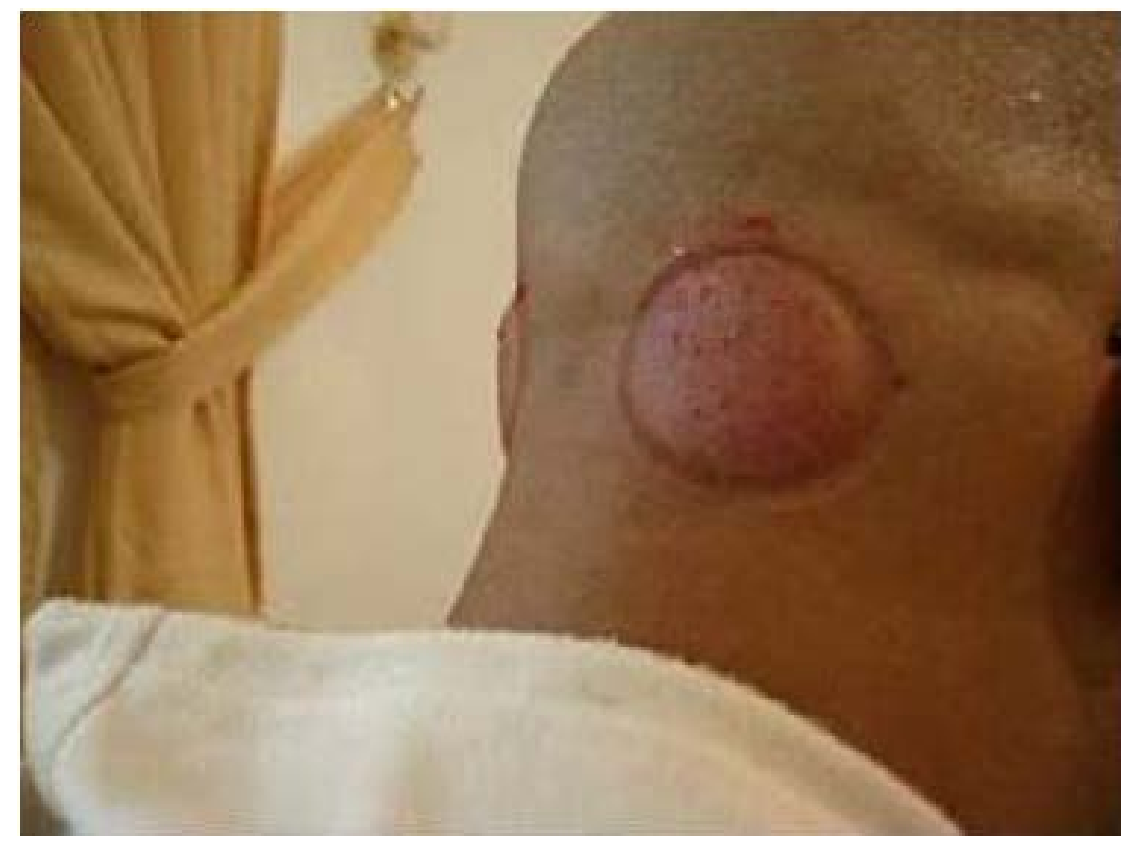

Figure 8. Post-cupping sign: a transient skin uplifting surrounded by a circular depression occurs after cupping therapy and disappears without any sequelae within few days. Post-cupping sign is to be differentiated from other skin signs e.g. in purpura [3] 
Most diseases are characterized by an abnormality in blood chemistry where a normal constituent may be high e.g. serum iron and ferritin in thalassemia or an abnormal constituent may be high e.g. serum autoantibodies in autoimmune diseases. Al-hijamah-induced non-specific clearance of the interstitial fluids and serum may normalize blood chemistry and restore physiological homeostasis through exerting multiple therapeutic functions (Table 4). The major therapeutic value in Al- hijamah over the Chinese WCT is the better blood clearance and excretion of the collected fluid mixture (containing CPS) through Al-hijamah as Al-hijamah is a two-step filtration process (suction pressure is applied twice), while Chinese WCT is a single step filtration process (suction pressure is applied once). [2,3] This ensures better clearance of blood and interstitial spaces during Al-hijamah.

Table 4. Therapeutic health benefits of Al-hijamah N.B. Al-hijamah treats disease conditions through making use of one or more health benefits

\begin{tabular}{|c|c|}
\hline $\begin{array}{l}\text { Health benefits of Al- } \\
\text { hijamah }\end{array}$ & Explanation \\
\hline $\begin{array}{l}\text { Preventive health } \\
\text { benefits }\end{array}$ & $\begin{array}{l}\text { Irough periodic clearance of blood (general effect) and interstitial spaces (local effect) from possible continuous } \\
\text { duction of pathological substances and through preventing their accumulation }[2,3] \text {. }\end{array}$ \\
\hline $\begin{array}{l}\text { Non-specific } \\
\text { biochemical clearance } \\
\text { of serum and interstitial } \\
\text { fluids }\end{array}$ & $\begin{array}{l}\text { This is the single most important therapeutic benefit of Al-hijamah. One session of Al-hijamah resulted in a significant } \\
\text { clearance of serum triglycerides, total cholesterol, LDL-cholesterol, ferritin (circulating iron stores), uric acid, [1] } \\
\text { autoantibodies, cytokine receptors and others [16] i.e. Al-hijamah works through clearing blood from abnormally increased } \\
\text { normal constituents e.g. iron or newly added pathological substances e.g. autoantibodies. }\end{array}$ \\
\hline Excretory benefit & $\begin{array}{l}\text { Through the non-specific pressure-dependent and size-dependent filtration function of Al-hijamah, large macromolecules } \\
\text { e.g. globulins; antibodies and rheumatoid factor }{ }^{16} \text { can be excreted. Also, both hydrophilic and hydrophobic substances } \\
\text { (triglycerides, cholesterol and LDL) can be excreted, }{ }^{1} \text { which is more excretory than renal glomerular excretion. }\end{array}$ \\
\hline Detoxification benefit & $\begin{array}{l}\text { Due to the proved clearance effects of the blood and interstitial fluids from endogenous toxins and exogenous toxins }{ }^{17} \\
\text { exerted by Al-hijamah }[1,16]\end{array}$ \\
\hline Metabolic benefit & $\begin{array}{l}\text {-hijamah may improve cellular perfusion secondary to improving local capillary circulation and removal of vascular } \\
\text { ngestion. Al-hijamah may clear blood from accumulated cellular metabolites e.g. ferritin, urea and uric acid [1] }\end{array}$ \\
\hline $\begin{array}{l}\text { Pharmacological } \\
\text { potentiation benefit }\end{array}$ & $\begin{array}{l}\text { Being a mechanical procedure, there is no chemical or pharmacological antagonism of Al-hijamah with administered drugs. } \\
\text { Through removing pathological substances (targets of pharmacotherapy) from blood and interstitial fluids, Al-hijamah will } \\
\text { potentiate and facilitate therapeutic effects of drugs. }\end{array}$ \\
\hline $\begin{array}{l}\text { Anti-nociceptive } \\
\text { (Analgesic) benefit }\end{array}$ & $\begin{array}{l}\text { Al-hijamah may dilute chemical substances, inflammatory mediators, nociceptive substances and redistribute them away } \\
\text { from pain-sensitive structures [2,3] } \\
\text { Al-hijamah may bathe nerve endings in collected fluids inside the skin uplifting (skin dome) and breaks tissue adhesions } \\
\text { causing decreased pain [2,3]. } \\
\text { Immediately after skin scarifications, endogenous opioids e.g. endorphins, dynorphins and encephalin are produced [93] } \\
\text { Evidenced by the reported therapeutic effect of traditional WCT in clearing serum from substance P (Pain-mediating } \\
\text { substance) [94] }\end{array}$ \\
\hline $\begin{array}{l}\text { Anti-i } \\
\text { benef }\end{array}$ & $\begin{array}{l}\text { Evidenced by the reported therapeutic effects of Al-hijamah in clearing localized cellulitis from bacteria and bacterial toxins } \\
\text { [2,17]. } \\
\text { Evidenced by the reported therapeutic effects of Al-hijamah in clearing serum of rheumatoid patients from inflammatory } \\
\text { mediators (SIL-2R), autoantibodies and normalizing the acute phase reactants e.g. ESR and CRP [16] } \\
\text { Evidenced by the reported therapeutic effect of traditional WCT in clearing serum from substance P (Pain-mediating } \\
\text { substance) [94]. }\end{array}$ \\
\hline Hemodynamic benefit & $\begin{array}{l}\text { h removes vascular congestion and improves the blood flow and circulation. It drains excess fluids and treats } \\
\text { on }[1,2,3]\end{array}$ \\
\hline Hematological benefit & $\begin{array}{l}\text { ar blood from fragments of hemolyzed cells, liberated hemoglob } \\
\text { ss iron }[20,21] \text { in healthy subjects [1] and thalassemia. }\end{array}$ \\
\hline Hemostatic benefit & during Al-hijamah) with collected fluids inside skin uplifting will \\
\hline Homeostatic benefit & $\begin{array}{l}\text { endocrine balance (excretion of excess hormones and metabolites), physiology and normal } \\
\text { ue fluids (due to removal of CPS) [2,3]. }\end{array}$ \\
\hline Circulatory & $\begin{array}{l}\text { Through enhancing endogenous production of nitric oxide }[2,3,70] \text { improving capillary and lymphatic circulation, }{ }^{2-3} \\
\text { enhancing local blood flow, preserving underlying and remote tissue structure [96] }\end{array}$ \\
\hline Respirat & $\begin{array}{l}\text { Al-hijamah + pharmacotherapy) included improvements in } \\
\text { iever, exacerbations, eosinophil cationic protein, peripheral } \\
\text { s (from } 25 \%-75 \% \text { ) [24] }\end{array}$ \\
\hline Neurological benefit & $\begin{array}{l}\text { Through improving headache, [15] treating predisposing factors for neurological diseases e.g. hypertension, }{ }^{1} \text { modulating } \\
\text { pain transmission [16] and pain-causing substances, enhancing production of endogenous opioids and excreting CPS of } \\
\text { headache and migraine }\end{array}$ \\
\hline Immunological benefit & $\begin{array}{l}\text { Through enhancing the natural immunity (inducing physiological leukocytosis and increasing the number of natural killer } \\
\text { cells), [16] enhancing the production of endogenous nitric oxide (antimicrobial, immunomodulator and vasodilator, [2,3,70] } \\
\text { and production of antimicrobials peptides e.g. the cathelicidins, defensins, and dermcidins [2,3,97]. } \\
\text { The levels of immune stimulatory cells and cytokines increased e.g.T helper cells (CD4+), ratio of (T helper/T-cytotoxic } \\
\text { cells) (CD4+ /CD8+), interleukin-2 (Il-2), interferon-gamma, complement-3, complement-4, immunoglobulins IgA, IgG } \\
\text { and IgM [40] } \\
\text { The levels of immune inhibitory cytokines decreased e.g. IgE, IL-4, IL-10 and CD8+ decreased after treatment with } \\
\text { cupping therapy [40] }\end{array}$ \\
\hline Cosmetic benefit & $\begin{array}{l}\text { Through breaking tissue adhesions, resolving inflammation and swelling. [2,3,37] Recently, cupping therapy was reported } \\
\text { to treat vitiligo [44] }\end{array}$ \\
\hline 1080 & $\begin{array}{l}\text { Al-hijamah induces production of nitric oxide. [2,3,70] Nitric oxide may stimulate VEGF (angiogenic growth factor) } \\
\text { production }[2,3,98]\end{array}$ \\
\hline Physiotherapy benefit & $\begin{array}{l}\text { Al-hijamah decreases vascular congestion, improves microcirculation and treats peripheral ischemia. [2,3] Al-hijamah } \\
\text { increases the blood flow to ischemic tissues and may have a physiotherapy effect. [2,3] Cupping therapy is better than } \\
\text { acupuncture in treating hemiplegic shoulder pain and high upper-limb myodynamia after stroke. Favorable effects of } \\
\text { cupping on aphasia and intractable hiccup after stroke were also reported [73] }\end{array}$ \\
\hline
\end{tabular}




\begin{tabular}{|c|c|}
\hline $\begin{array}{l}\text { Treatment of disease } \\
\text { predisposing factors. }\end{array}$ & $\begin{array}{l}\text { Cupping therapy was reported to lower blood pressure significantly, [1] treat trigeminal neuralgia [36] (predisposing to } \\
\text { headache) and improve both serum lipid profile [1] (predisposing to atherosclerosis) and serum uric acid (predisposing to } \\
\text { gouty arthritis) significantly [1]. }\end{array}$ \\
\hline & $\begin{array}{l}\text { Through significantly removing accumulated metabolites that may harm tissues e.g. bacterial toxins in cellulitis, [2,17] } \\
\text { ferritin [1] and iron [20,21] (may be harmful in iron overload conditions) and glycosylated proteins in tissues of diabetic } \\
\text { patients [99] }\end{array}$ \\
\hline $\begin{array}{l}\text { Hepatoprotective } \\
\text { benefits }\end{array}$ & $\begin{array}{l}\text { Al-hijamah was reported to treat viral hepatitis, }[22,23] \text { decrease serum lipid profile and increase serum high density } \\
\text { lipoproteins [1]. } \\
\text { Excretory, blood clearance and detoxification therapeutic benefits of Al-hijamah may decrease the metabolic burden upon } \\
\text { the liver and protect hepatocytes. } \\
\text { Al-hijamah-induced iron and ferritin excretion [1] may be hepatoprotective. } \\
\text { Al-hijamah-induced pharmacological potentiation [16] may decrease the need for increasing drug dosage (may be } \\
\text { hepatotoxic) or drug administration (may be hepatotoxic). } \\
\text { Al-hijamah-induced decrease in side effects of pharmacological treatments [16] may be hepatoprotective. }\end{array}$ \\
\hline $\begin{array}{l}\text { Cardioprotective } \\
\text { benefits }\end{array}$ & $\begin{array}{l}\text { Al-hijamah significantly improved the ischemia- induced arrhythmias in experimental animals, without changing the } \\
\text { baseline heart rate or the mean arterial blood pressure [43]. } \\
\text { Al-hijamah decreased significantly the size of experimental infarcts and the incidence of fatal arrhythmias [43]. } \\
\text { Al-hijamah-induced iron and ferritin excretion }{ }^{1} \text { may be cardioprotective } \\
\text { Al-hijamah decreases blood pressure, serum cholesterol, triglycerides and LDL significantly [1] } \\
\text { Cupping (e.g. Al-hijamah) was reported to be cardioprotective through restoring the sympathovagal imbalances by } \\
\text { stimulating the peripheral nervous system [100] }\end{array}$ \\
\hline Neuroprotective benefits & $\begin{array}{l}\text { WCT protects against and treats infections caused by neurotropic viruses e.g. herpes viruses [26] } \\
\text { Al-hijamah-induced serum clearance from toxic metabolites may be neuro-protective } \\
\text { Al-hijamah-induced decrease in side effects of pharmacological treatments [16] may be neuro-protective.. }\end{array}$ \\
\hline & $\begin{array}{l}\text { Al-hijamah-induced decrease in side effects of pharmacological treatments [16] may be nephroprotective. } \\
\text { Excretory, blood clearance and detoxification therapeutic benefits of Al-hijamah may decrease the metabolic burden upon } \\
\text { the kidney and protect the nephrons. }\end{array}$ \\
\hline $\begin{array}{l}\text { Anti-hypertensive } \\
\text { benefit }\end{array}$ & $\begin{array}{l}\text { Al-hijamah was reported to decrease systolic and diastolic blood pressure significantly [1]. } \\
\text { Al-hijamah-induced fluid excretion may decrease the volume overload encountered in some hypertensive patients. }\end{array}$ \\
\hline & $\begin{array}{l}\text { Al-hijamah was reported to decrease serum cholesterol, triglycerides and LDL [1]. } \\
\text { Al-hijamah was reported to increase serum HDL [1]. }\end{array}$ \\
\hline Anti-allergic benefits & $\begin{array}{l}\text { Al-hijamah was reported to clear serum from IgE, IL-2 and C3 significantly [48] } \\
\text { Al-hijamah was reported to treat some allergic diseases e.g. chronic idiopathic urticaria [48] } \\
\text { Al-hijamah was reported to improve the performance of the immune system [16,40] }\end{array}$ \\
\hline Anti-infective benefit & $\begin{array}{l}\text { Through percutaneous pathogen excretion e.g. excretion of bacteria and bacterial toxins in case of cellulitis [2,17] } \\
\text { Al-hijamah-induced blood clearance may excrete pain mediators, exert antimicrobial effect (through inducing production of } \\
\text { endogenous nitric oxide }[2,3,70] \text { and antimicrobials peptides) [88] and improve natural immunity [16]. }\end{array}$ \\
\hline Antiviral benefits & $\begin{array}{l}\text { WCT was reported to treat herpes virus infections [26]. } \\
\text { Al-hijamah was reported to treat viral hepatitis [22,23] and enhance natural antiviral immunity [6,22,23] } \\
\text { May filter and excrete viral particles in cupped blood. } \\
\text { The levels of immune stimulatory cells and cytokines increased e.g.T helper cells (CD4+), ratio of (T helper/T-cytotoxic } \\
\text { cells) (CD4+/CD8+), interleukin-2 (Il-2), interferon-gamma, complement-3, complement-4, immunoglobulins IgA, IgG } \\
\text { and IgM [40] } \\
\text { The levels of immune inhibitory cytokines decreased e.g. IgE, IL-4, IL-10 and CD8+ decreased after treatment with } \\
\text { cupping therapy [40] }\end{array}$ \\
\hline Anti-rheumatic benefits & $\begin{array}{l}\text { Al-hijamah was reported to clear serum from autoantibodies [16]. } \\
\text { Al-hijamah was reported to clear serum from inflammatory mediators associated with autoimmune diseases e.g. SIL-2R } \\
\text { [16] } \\
\text { Al-hijamah was reported to improve the acute phase reactants and the clinical parameters associated with the rheumatic } \\
\text { diseases e.g. ESR and CRP [16] }\end{array}$ \\
\hline Anti-cancer benefits & $\begin{array}{l}\text { Evidenced by the reported benefits of Al-hijamah in enhancing the natural immunity, [16] exerting pharmacologica } \\
\text { potentiation, [16] and excreting pathology-related substances (e.g. non-specific blood clearance may excrete pain-causing } \\
\text { substances, [16] excess growth factors of cancer cells, tumor cell products and others). NO (produced during Al-hijamah) } \\
\text { has both anti-neoplastic and anti-proliferative effects }[2,3,70]\end{array}$ \\
\hline Nutritional benefit & Through decreasing accumulated nutritional metabolites in blood e.g. elevated LDL and cholesterol [1]. \\
\hline & Through enhancement of immunity, [16] circulation [2,3] and removal of the pathological substances $[1,2,3,16]$. \\
\hline Psychological benefit & Secondary to all benefits and due to improvement of the affective component of pain. \\
\hline $\begin{array}{l}\text { (Albedah et al.) sear } \\
\text { using complementary } \\
\text { ACP journal club, } \\
\text { Cochrane database } \\
\text { methodology registe } \\
\text { effects, health } \\
\text { Journals@Ovid, M } \\
\text { evaluation database. } \\
\text { We agree with the }\end{array}$ & $\begin{array}{l}\text { both types of WCT and when interpreting the validity of } \\
\text { Al-hijamah in treating different disease conditions. We } \\
\text { agree with Albedah et al. in evaluating the therapeutic } \\
\text { outcomes of WCT (both types) and in reaching the conclusion } \\
\text { that WCT is effective for treating pain conditions. } \\
\text { However, regarding the therapeutic effects of cupping } \\
\text { therapy in treating other disease conditions e.g. stroke } \\
\text { rehabilitation, it was not clear which type of cupping } \\
\text { therapy is meant by the conclusion drawn by the authors } \\
\text { that the evidence is minimal. [11] Moreover, Al-hijamah } \\
\text { treats predisposing factors for stroke progression e.g. } \\
\text { hypertension, hyperlipidemia and others [1] and this is } \\
\text { very important and beneficial for the patients regarding } \\
\text { improving the current stroke condition and preventing }\end{array}$ \\
\hline
\end{tabular}


opinion: first, it is advisable to differentiate research results of Al-hijamah (triple $\mathrm{S}$ technique) from research results of traditional Chinese WCT (double S technique) through comparing the methodology done and outcome of studies. Second, we hope if the authors in the future studies mention some details regarding these pain conditions or the rationale beyond their improvement. Third, we hope if they comment on cupping therapy regarding the type of treatment given and the beneficial effects of traditional WCT versus Al-hijamah in treating other diseases e.g. hypertension, fibromyalgia, headache, cellulitis, carpal tunnel syndrome, rheumatoid arthritis (RA), headache, migraine and others. [2] Fourth, we hope that the conclusion addressed by the authors sticks more to Al-hijamah rather than to other types of cupping therapy as research studies done in Al-hijamah are very few. Our understanding to the therapeutic benefits of Al-hijamah in light of future publications may expand the therapeutic spectrum of Al-hijamah in light of better understanding of its medical and scientific bases [2,3,7].

\section{Therapeutic Benefits of Al-hijamah}

Despite simplicity of the technique of Al-hijamah, many therapeutic benefits can be gained from it e.g. nonspecific blood clearance, pain relief, pharmacological potentiation, restoring homeostasis and others. [2,3] On the other side, there is no reported risk or harm that can be attributed to Al-hijamah. This confers many therapeutic advantages exerted by Al-hijamah over other conventional therapeutics. Table 4 lists some health benefits related to the practice of Al-hijamah. Nitric oxide (NO) is produced endogenously in enormous amounts as a response to skin injury $[2,12,13]$. (e.g. skin scarifications occurring during Al-hijamah). Interestingly, NO is the functional metabolite of some widely used drugs e.g. nitroglycerine for treating coronary artery ischemia (through inducing coronary dilatation) and sodium nitroprusside for treating severe hypertension. Sodium nitoprusside acts as NO donors. [14] Nitroglycerine and sodium nitroprusside were reported to have powerful actions to dilate blood vessels e.g. the radial artery. NO was reported to induce a decrease in the pressure wave reflection and systolic blood pressure better than phentolamine ( $\alpha$-adrenergic antagonist), verapamil (calcium-channel antagonist) and hydralazine (arterial vasodilator) [14].

\section{Al-hijamah as a Pharmacological Potentiator}

Al-hijamah was reported to have excellent therapeutic effects when it was used as a sole treatment [15] and as a combined treatment with conventional pharmacological treatments. [16] Many disease conditions responded better to Al-hijamah than to conventional pharmacological treatments. [15,16,17] However, Al-hijamah is not a substitute for pharmacological treatments. Instead, Alhijamah may act as a pharmacological potentiator. Pharmacological potentiation is the sole target of drug combinations when treating various diseases and aims at gaining synergistic therapeutic effects via making benefits of combining more than one drug acting through more than one mechanism of action. It aims also at decreasing drug dose, frequency of drug administration and possible side effects. Contrary to that is drug-drug antagonism due to both chemical and pharmacological interactions where one drug decreases pharmacological actions and therapeutic effects exerted by another drug. Being a nonchemical and non-pharmacological therapy, Al-hijamah does not have any antagonistic effects with any therapeutic drug or pharmacological treatments. Moreover, Al-hijamah was reported to exert pharmacological potentiation with pharmacological treatments for treating many diseases e.g. RA [16] and headache [15]. Alhijamah removes CPS from the site of pathology (whether the pathology is localized or generalized), from blood and from interstitial fluids. This enables pharmacological treatments to do better against a lower concentration of CPS, which prepares the site of pathology for a better response to administered pharmacological therapeutics. This may give a better chance for the immune system and homeostatic mechanisms to do better. $[15,16,17]$ Sahbaa et al. reported that combination of bloodletting WCT (Alhijamah) with anti-rheumatoid drugs was synergistic and did better than the mere use of conventional antirheumatoid drugs. [16] They reported also that conventional anti-rheumatoid drugs (e.g. methotrexate) induced a significant decrease in white blood cell count (bone marrow suppression) whereas combined therapy (Al-hijamah plus methotrexate) induced leukocytosis. [16] Moreover, the count of natural killer cells significantly decreased with conventional therapy and significantly increased with combined therapy. [16] In RA, soluble interleukin-2 receptors (SIL-2R) is strongly correlated with disease progression, pain intensity (measured by visual analogue scale, VAS), tender joint count (TJC), swollen joint count (SJC), disease activity scores (DAS) and laboratory markers of disease activity e.g. erythrocyte sedimentation rate (ESR), C-reactive protein (CRP) and rheumatoid factor. [16] The authors reported that combined therapy resulted in a significant reduction in concentration of SIL-2R over three successive months of treatment compared to base line levels while there was no significant reduction when conventional therapy was used. [16] Improvements occurred in a time-dependent manner [16].

Moreover, Ahmadi et al. reported that when treating patients suffering from migraine headache with Alhijamah, clinical improvements were recorded in the form of reductions of the mean headache severity, duration (in days) of headache and frequency of medication administration [15].

\section{Therapeutic Indices of Al-hijamah}

To evaluate and quantitate the therapeutic benefits gained after performing Al-hijamah, many novel therapeutic indices of Al-hijamah can be calculated. Being novel determinants for the efficiency of Al-hijamah, therapeutic indices evaluate the technique done, practitioner's skills and patient's response to treatment and may help future follow-up of treatment. Therapeutic indices of Al-hijamah include excretion value, purification index, pharmacological potentiation index, immunological index and clinical therapeutic index. 


\section{Excretion Value}

Excretion value (EV) is the quantity of CPS excreted after the end of the session of Al-hijamah. EV can be calculated from the formula: $\mathrm{EV}=$ (Initial concentration of any substance in serum before Al-hijamah in concentration unit/blood volume unit) - (concentration of the same substance in serum after Al-hijamah in concentration unit/blood volume unit). EV should be performed within the first 24 hour after Al-hijamah.

Clinical importance of EV comes from quantitating the efficiency of Al-hijamah in excreting a substance from serum i.e. pure excretory function of Al-hijamah. EV can judge the best hand skills among different practitioners of Al-hijamah depending on comparing the excretory effects of Al-hijamah. As EV can be affected by many variables of Al-hijamah technique e.g. anatomical sites for practicing Al-hijamah, pressure inside cups, time for cups application, number of skin scarifications and others, EV can be used to standardize Al-hijamah by choosing the best of those variables in light of future research.

As a practical example, Sahbaa et al. [16] treated RA with Al-hijamah where they reported a decrease in serum level of some CPS related to the pathogenesis of RA. In the patients' group who received combined treatment (Alhijamah and pharmacotherapy), rheumatoid factor decreased from $131.47 \mathrm{IU} / \mathrm{ml}$ to $51.54 \mathrm{IU} / \mathrm{ml}$ (Table 5). This means that EV for rheumatoid factor is (131.47 $51.54=80.02 \mathrm{IU} / \mathrm{ml})$ while EV for SIL-2R is $(2023-$ $1790=233 \mathrm{pg} / \mathrm{ml}) .{ }^{16}$ In another practical report in healthy subjects, the author reported a significant decrease in serum uric acid, ferritin, total cholesterol, LDL-cholesterol and triglycerides after Al-hijamah for healthy subjects. EV for uric acid was $(4.5-3.7=0.8 \mathrm{mg} / \mathrm{dl})$, $\mathrm{EV}$ for total cholesterol was $(158-136.3=21.7 \mathrm{mg} / \mathrm{dl})$, EV for serum triglycerides was $(164.9-119.8=45.1 \mathrm{mg} / \mathrm{dl})$, EV for LDL-cholesterol was (71.8-55.1=16.7 $\mathrm{mg} / \mathrm{dl})$ and $\mathrm{EV}$ for ferritin was $(129.4-100.6=28.8 \mathrm{ng} / \mathrm{ml})[1]$.

Table 5. Therapeutic benefits exerted by Al-hijamah in treating rheumatoid patients by Sahbaa et al. [16] N.B. Group I: Patients who received conventional pharmacotherapy for RA; Group II: Patients who received conventional pharmacotherapy for RA + Al-hijamah

\begin{tabular}{|c|c|c|c|c|}
\hline Parameters & Base line & After 1 month & After 2 months & After 3 months \\
\hline Gaoup I & & & & \\
\hline VAS & $800 \pm 0.34$ & $7.10 \pm 0.38$ & $6.30 \pm 0.40$ & $6.25 \pm 1.33$ \\
\hline TJC & $19.35 \pm 0.97$ & $19.30 \pm 0.95$ & $18.10 \pm 0.40$ & $12.8 \pm 54.01$ \\
\hline SJC & $14.70 \pm 1.02$ & $14.50 \pm 1.10$ & $13.75 \pm 0.91$ & $12.95 \pm 3.66$ \\
\hline DAS & $6.14 \pm 0.13$ & $6.09 \pm 0.13$ & $6.01 \pm 0.14$ & $5.92 \pm 0.61$ \\
\hline ESR (mm/hr) & $41,15 \pm 3.97$ & $40.55 \pm 4.11$ & $42.55 \pm 4.17$ & $42.95 \pm 4.49$ \\
\hline CPR (mg/dl) & $48.60 \pm 5.93$ & $46.6 \pm 6.57$ & $46.80 \pm 5.14$ & $41.10 \pm 22.74$ \\
\hline $\mathrm{RF}(\mathrm{IU} / \mathrm{ml})$ & $129.75 \pm 27.17$ & $122.00 \pm 27.38$ & $104.65 \pm 28.48$ & $92.36 \pm 15.12$ \\
\hline SIL-2R(pg/ml) & $2020 \pm 526.75$ & & & $2007 \pm 525.57$ \\
\hline
\end{tabular}

Group II

VAS

TJC

SJC

DAS

$\operatorname{ESR}(\mathrm{mm} / \mathrm{hr})$

CPR (mg/dl)

$\mathrm{RF}(\mathrm{IU} / \mathrm{ml})$

$\operatorname{SIL-2R}(\mathrm{pg} / \mathrm{ml})$
Patients who received Al-hijamah plus conventional pharmacological treatment

$\begin{array}{cccc}7.80 \pm 0.28 & 5.16 \pm 0.28 & 4.70 \pm 0.32 & 3.20 \pm 1.54 \\ 19.53 \pm 0.95 & 11.26 \pm 1.03 & 9.86 \pm 1.04 & 4.73 \pm 2.76 \\ 15.83 \pm 0.97 & 40.56 \pm 3.36 & 7.3 \pm 0.73 & 3.56 \pm 1.99 \\ 6.15 \pm 0.10 & 5.35 \pm 0.14 & 4.94 \pm 0.14 & 4.10 \pm 0.69 \\ 44 \pm 13.90 & 40.56 \pm 3.36 & 38.66 \pm 3.31 & 36.46 \pm 3.35 \\ 46.40 \pm 5.45 & 26.90 \pm 3.68 & 18.20 \pm 0.36 & 9.60 \pm 1.90 \\ 131.47 \pm 23.89 & 51.46 \pm 6.66 & 26.40 \pm 2.66 & 19.01 \pm 3.49 \\ 2023 \pm 508.46 & & & \mathbf{1 7 8 9 . 3 4}\end{array}$

effect when comparing the effect of pharmacological treatments combined with Al-hijamah versus pharmacological treatments only in decreasing the serum concentration of a noxious substance. PI estimates the rate of re-accumulation of a given CPS at different time points, which will facilitate estimating the proper time for performing the next session of Al-hijamah. PI measures also the combined therapeutic benefits of the excretory, immunological and pharmacological potentiation effects of Al-hijamah.

Taking Sahbaa's report [16] as a practical example, PI for rheumatoid factor $=[100 \mathrm{X}(131.47-51.54 / 131.47)]=$ $42 \%$ i.e. one month after Al-hijamah, patients' serum was cleared from about $42 \%$ of its initial rheumatoid factor concentration before treatment. Serum clearance increased further to $60.8 \%$ after the second month of treatment (Table 5) and increased to 79.9\% (Table 5) after the third given CPS. PI can judge the pharmacological potentiation 
month of treatment. PI for SIL-2R was [100X (2023 $1790 / 2023)]=11.5 \%$.

In the second above-mentioned practical report, [1] PI for uric acid was $[100 \mathrm{X}(4.5-3.7) / 4.5]=17.78 \%$, PI for total cholesterol was [100X (158-136.3)/158)] = 13.7\%, PI for serum triglycerides was [100X (164.9-119.8)/164.9] = 27.3\%, PI for LDL-cholesterol was [100X (71.8$55.1) / 71.8]=23.2 \%$ and PI for ferritin was [100X (129.4$100.6=28.8 \mathrm{ng} / \mathrm{ml})]=22.2 \%$. [1] Based on that, Alhijamah (as a single session or multiple sessions) may be efficient as a therapeutic modality against the risk factors for developing coronary diseases, atherosclerosis, gout, iron overloading conditions e.g. thalassemia and others. Interestingly, unlike Al-hijamah, traditional WCT was reported to be not significant in improving risk factors of coronary heart disease where the lipid profile status did not differ significantly between the patients who received dietary advice alone and those who received dietary advice combined with WCT. [18] In a similar issue, Alhijamah was reported to decrease serum ferritin level (circulating iron stores) significantly, [1] which strongly recommends Al-hijamah as a promising treatment for anemic diseases characterized by iron overload e.g. thalassemia. More interestingly, Al-hijamah does not induce a significant blood loss, which keeps the red cell mass and hemoglobin level within the normal range [19]. On the other hand, excessive WCT (in multiple number of sessions or amount of bloodletting) reduced serum iron maximally and induced iron-deficiency anemia. [20,21] This may confirm superiority of Al-hijamah over traditional WCT as Al-hijamah is a filtration-dependent excretory procedure (that excretes disease CPS) rather than a bloodletting technique [2,3] i.e. Al-hijamah does not cause excessive blood loss. Al-hijamah was reported as the only form of cupping therapy to treat viral hepatitis where Al-hijamah reduced hepatitis C virus RNA load from $(3.52 \pm 0.53)\left(\mathrm{X} 10^{5} \mathrm{IU} / \mathrm{ml}\right)$ to $(2 \pm 0.38)(\mathrm{X} 105$ $\mathrm{IU} / \mathrm{ml}$ ). There was a seroconversion from positive PCR to negative PCR in $10 \%$ of cases This means that Al-hijamah cleared patients' blood from hepatitis viruses (through both excretory and immunological functions of Alhijamah) by about $43.18 \%[22,23]$.

\section{Pharmacological Potentiation Index}

Pharmacological potentiation index (PPI) measures the degree of pharmacological potentiation when combining Al-hijamah with conventional pharmacological treatments versus the mere use of conventional pharmacological treatment. PPI records the best drug combinations to be administered with Al-hijamah. PPI= [100 X (Therapeutic effects of Al-hijamah + conventional pharmacological treatments)/ (Therapeutic effects of conventional pharmacological treatments only)].

Taking Sahbaa's report [16] as a practical example (Table 5), PPI for improving pain intensity was [100 X $(7.8-5.6) /(8-7.1)]=244.4 \%$ i.e. combination of $\mathrm{Al}-$ hijamah with conventional treatments for RA increased pharmacological potency of conventional pharmacotherapy treatments by $244.4 \%$. Moreover, PPI for decreasing serum rheumatoid factor was [100 X $(131.47-51.46) /(129.75-122)]=1032 \%$.

\section{Immunological Index}

Immunological index (II) measures the degree of immunological response to Al-hijamah whether the response was a decrease in pathological immunity (e.g. autoimmunity) or an increase in natural immunity e.g. leukocytosis and lymphocytosis. $\mathrm{II}=\left[\begin{array}{ll}100 & \mathrm{X}\end{array}\right.$ (Immunological response after Alhijamah)/(Immunological response before Al-hijamah)].

Taking Sahbaa's report [16] as a practical example (Table 5), II for induction of leukocytosis $=[100 \mathrm{X}$ $(10.05 / 6.94)]=.156 \%$ i.e. natural immunity (using leukocytosis) increased by $156 \%$ after combination of Alhijamah with conventional pharmacological treatment. Moreover, II for increasing natural killer lymphocytes was $[100 \mathrm{X}(11.33 / 8.5)]=.133 \%$ i.e. natural immunity using NK cells increased by about 133\% after Al-hijamah.

\section{Clinical Therapeutic Index}

Clinical therapeutic index (CTI) is the percentage improvement of a tested clinical parameter (e.g. pain intensity, disease activity, blood pressure value and others) after Al-hijamah (as a sole treatment or as a combined treatment) measured at different time points. CTI can be calculated from the formula: CTI $=[100 \mathrm{X}$ (clinical parameter before Al-hijamah- clinical parameter after $\mathrm{Al}$ hijamah)/ clinical parameter before Al-hijamah]. CTI should be measured at many time points after Al-hijamah. CTI can evaluate the clinical therapeutic efficacy of Alhijamah for treating a given disease. CTI can correlate PI with the clinical outcome after Al-hijamah. CTI can quantitate the percentage of clinical improvement at different time points and estimate the longevity of improvement after one session of Al-hijamah and compare the degree of synergism with pharmacological treatments. CTI may record occurrence of any side effects or any signs of malpractice.

Abd al-Jawad et al. [24] reported a significant statistical improvement in clinical indices in asthma patients when combining Al-hijamah with asthma pharmacotherapy better than asthma pharmacotherapy as a sole treatment. Reported improvements included daytime symptoms, nocturnal symptoms, need for reliever, exacerbations, eosinophil cationic protein, peripheral esinophilic count and improvement in respiratory function tests (from 25\%75\%) [24].

Taking Sahbaa's report [16] as another practical example (Table 5), CTI for improving pain intensity (measured by VAS) is [100 X (7.8-4.7)/7.8] $=33.8 \%$ one month after performing Al-hijamah combined with conventional treatment i.e. pain intensity decreased by $33.8 \%$ one month after treatment then decreased by [100 $\mathrm{X}(7.8-5.16) / 7.8]=39.7 \%$ two month after treatment and finally decreased by $[100 \mathrm{X}(7.8-3.2) / 7.8]=58.9 \%$ three months after treatment. Moreover, CTI for improving TJC in rheumatoid patients treated by combined Al-hijamah with pharmacological treatments (within the same time period) was $42 \%, 50$ and $75.7 \%$, respectively. CTI for improving SJC in rheumatoid patients treated by combined Al-hijamah with pharmacological treatments (within the same time period) was 32\%, 53.8 and $77.8 \%$, respectively. CTI for improving ESR in rheumatoid 
patients treated by combined Al-hijamah with pharmacological treatments (within the same time period) was $7.8 \%, 12.1$ and $21.6 \%$, respectively. CTI for improving CRP values in rheumatoid patients treated by combined Al-hijamah with pharmacological treatments (within the same time period) was $42 \%, 60$ and $77 \%$, respectively.

\section{Therapeutic Indications and Diseases Reported to be Treated by Cupping Therapy}

Recently, Lauche et al. reported clinical improvements in treating pain, disability and quality of life for chronic non-specific neck pain on cupping therapy as evidenced by reanalysis of four randomized controlled trials measured by visual analog scale (VAS) in these trials [25].

Cupping therapy effectively treated musculoskeletal pain conditions as lumbar disc herniation, cervical spondylosis, [26] brachialgia paraesthetica nocturna, [27] persistent non-specific low back pain, [28] fibrositis, [29] firomyalgia, [30] chronic non-specific neck pain,31 chronic knee osteoarthritis [32] and other pain conditions e.g. pain of dysmenorrhea [33] and pain of acute gouty arthritis [34].

Recently, we reported Al-hijamah as a suggested novel treatment for percutaneous excretion of iron and ferritin for treating thalassemia, hemochromatosis and other conditions of iron overload [35].

Cupping therapy effectively treated neurological conditions as headache and migraine, [15] acute trigeminal neuralgia [36] and carpal tunnel syndrome [37].
Cupping therapy was also effective in treating metabolic conditions e.g. acute gouty arthritis, [34] hyperlipidemia and hypercholesterolemia. [38] Cupping therapy was effective in treating respiratory diseases e.g. allergic rhinitis, [39] asthma [24] and asthmatic bronchitis [40].

Moreover, cupping therapy was effective also in treating some cardiovascular diseases e.g. systolic hypertension, [41] circulatory overload, heart failure, [42] arrhythmia, myocardial infarction (in experimental animals where WCT decreased the size of the cardiac infarct) [43].

Cupping therapy was effective in treating viral infections e.g. herpes zoster, [26] viral hepatitis [22,23] and bacterial infections e.g. cellulitis. [17] Cupping therapy was effective in treating autoimmune diseases e.g. RA, [16] vitiligo [44] and other disease conditions e.g. secondary amenorrhoea [45] and stroke rehabilitation. [46] Cupping therapy was reported to reduce serum iron [47] and ferritin [1] in healthy subjects. Recently, Al-hijamah was reported to treat effectively some dermatological conditions e.g. acne vulgaris, chronic idiopathic urticaria and atopic dermatitis [48].

As Al-hijamah includes all steps of both Chinese DCT and WCT, therapeutic indications for performing Alhijamah includes all diseases treated by both Chinese DCT and WCT (Table 6). All the above-mentioned therapeutic benefits of Al-hijamah (Table 4) may participate in improving the therapeutic outcome exerted by Al-hijamah in treating such disease conditions.

Table 6. Therapeutic indications of Al-hijamah (based on all therapeutic benefits of Al-hijamah)

N.B.

- Al-hijamah includes all steps, therapeutic benefits of both dry cupping therapy and Chinese wet cupping therapy. Therefore, Al-hijamah treats all indications treated by all forms of cupping therapy. The opposite is not true (other cupping therapies don't cover indications of Alhijamah).

- As Al-hijamah is more comprehensive in methodology than both traditional DCT and traditional WCT, all therapeutic benefits qained from traditional DCT and traditional WCT are also gained from Al-hijamah.

- Degree of therapeutic improvements after Al-hijamah vary from disease to disease and ranges from cure to clinical improvement according to disease pathogenesis and biology, optimization of practicing Al-hijamah technique (proper practice at proper anatomical sites with proper number of cups using proper suction pressure after inducing a proper shratat mihjam), co-administration of drugs and natural remedies of prophetic medicine (e.g. honey, nigella sativa, costus, ajwah of aliah and others).

- Deqree of improvement after Al-hijamah is dependent upon the how many therapeutic benefits (Table 4) were qained during treatment Therapeutic indications of Al-hijamah

1. Musculoskeletal pain conditions (Al-hijamah may excrete pain-causing substances, prostaglandins, inflammatory mediators and cytokines)

- Back pain and lumbar pain (lumbago)

- Cervical spondylosis and lumbar disc herniation

- Fibromyalgia and fibrositis

- Knee osteoarthritis

- Lumbar disc prolapse (as a non-surgical treatment unless surgery is indicated)

- Neck and shoulder pain

- Persistent non-specific low back pain

- Skeletal pain in general

- Shouder-back myofascitis

- Traumatic strain, sprain and post-fracture conditions

2. Cardiovascular diseases (Al-hijamah may excrete excess intravascular fluids, excess lipids, vasoconstrictors and pathology-related substances)

- Edema (to clear interstitial spaces from excess fluids)

- Hypertension (through excreting excess serum fluids and vasoconstrictors)

- Myocardial ischemia and arrhythmia

- Rheumatic fever

- Vascular thrombosis (e.g. in the leg)

3. Hematoloqical conditions (Al-hijamah may clear blood from the fragments of hemolyzed cells, liberated hemoglobin, excess iron and old RBCs)

- Thalassemia (to excrete excess serum iron, ferritin and fragmented cells)

- Bronze diabetes (to treat diabetic complications and excrete excess iron)

- Sickle cell anemia and hemolytic crises (Al-hijamah may clear blood from the fragments of hemolyzed cells, liberated hemoglobin, excess iron and old RBCs)

- Sideroblastic anemia (to excrete excess iron)

- Hemosiderosis and hemochromatosis (to excrete excess iron) 
- Hemolysis (to excrete liberated hemoglobin and fragmented cells)

4.Some dermatoloqical conditions (Al-hijamah may clear blood from fragments of abnormally high IgE and other disease CPS)

- Acne vulgaris

- Atopic dermatitis

- chronic idiopathic urticaria

5. Inborn errors of metabolism (to clear blood from accumulated substrates and metabolites. Al-hijamah-induced blood clearance may act as a substrate reduction therapy. Patients may benefit from Al-hijamah-induced enhancement of immunity and pharmacological potentiation)

- Alkaptonuria

- Ammonia (and urea cycle) metabolic disorders i.e. ammonia intoxication

- Essential pentosuria

- Fructosemia

- Galactosemia

- Gangliodidosis

- Gaucher's disease

- Glycogen storage diseases

- Homocysteinemia

- Maple syrup urine disease

- Mucopolysaccharidoses

- Neiman pick's disease

- Phenylketoneuria

6. Neuropsychiatric diseases (to excrete pain-causing substances, prostaglandins and pathology-related substances and enhance natural immunity)

- Brachialgia paraesthetica nocturna

- Carpal tunnel syndrome

- Early cerebral infarction

- Epilepsy

- Headache and Migraine

- Laziness, lassitude and somnolence

- Stroke patients

- Trigeminal neuralgia, trigeminal neuritis and facial neuritis

- Some psychiatric conditions

\section{Malignancy}

- Solid tumors (Al-hijamah may clear blood from cancer antigens, growth factors, angiogenesis factors and tumor cell products)

- Leukemias, lymphomas and multiple myeloma (Al-hijamah may clear blood from cancer antigens, growth factors, angiogenesis factors and $\mathrm{t}$ umor cell products)

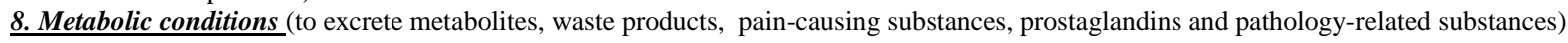

- Gout and gouty arthritis

- Thyroid dysfunction

- Conditions of hormonal imbalance

- Hyperlipidemia and hypercholesterolemia

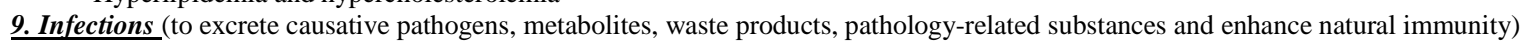

- Cellulitis

- Diabetic foot (to improve local circulation in the foot, enhance immunity, excrete abnormal metabolites, clear interstitial fluids from pathogens and make use of the endogenous NO-mediated vasodilatation)

- Some viral infections e.g. herpes zoster, influenza, epidemic flu, rabies and others (Al-hijamah enhances the natural antiviral immunity)

- Viral hepatitis B and C

10. Respiratory and ENT diseases (to excrete pathology-related substances and enhance natural immunity)

- Bronchial asthma

- Chronic sinusitis (antibiotic-resistant chronic sinusitis)

- Motion sickness

- Otitis media

- Tonsillitis

- Peumothorax

11. Autoimmune diseases (to excrete excess autoantibodies, immune complexes, cytokines, prostaglandins, pathology-related substances and enhance natural immunity)

- Ankylosing spondylitis

- Systemic lupus erythematosus

- Rheumatoid arthritis

- Thyroid autoimmunity (Grave's disease and Hashimoto's thyroiditis)

- Acanthosis nigricans

- Addison's disease

- Ankylosing spondylitis

- Autoimmune anemia and pernicious anemia

- Cold agglutinin disease

- Goodpasture's disease

- Insulin-dependent diabetes mellitus

- Multiple sclerosis

- Myasthenia gravis

- Rheumatoid arthritis

- Scleroderma

- Systemic lupus erythematosus

- Vitiligo

\section{Gastrointestinal diseases}

- Gastritis

- Intoxication (toxin, food and drugs administration) (to clear blood from toxins)

- Irritable bowel syndrome

- Chron's disease 


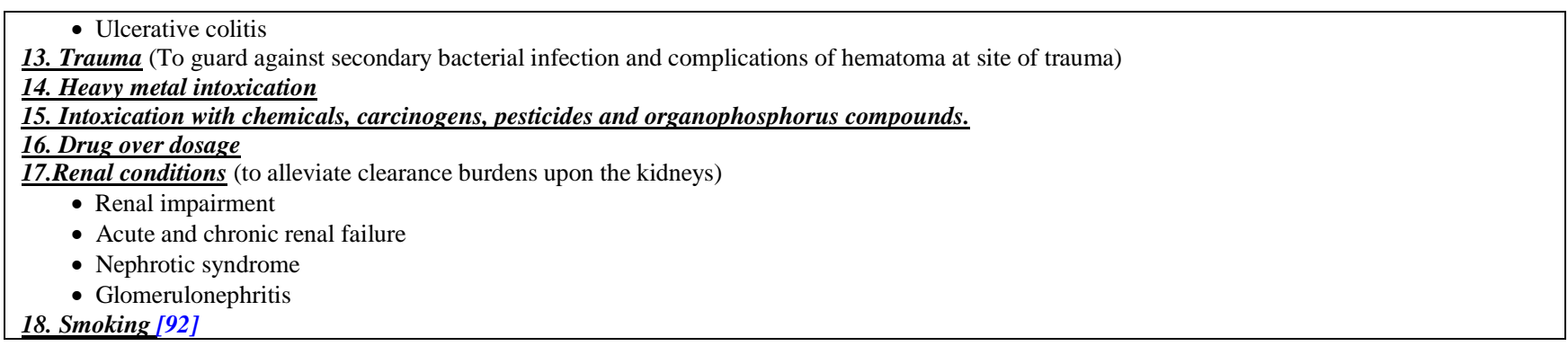

Table 7. Evidence-based medical and scientific lessons gained from prophetic medicine regarding Al-hijamah

Lessons gained from prophetic medicine regarding $\mathrm{Al}-$ hijamah

1. To put sucking cups during Al-hijamah directly above the site of pathology or as near as possible to the site of pathology e.g. at the trauma site on the thigh [101] and at the head regions for treating headache [102]

2 . To use the kahel region (back region including skin over the $7^{\text {th }}$ cervical vertebra) and akhdayin regions (regions in the neck lying postero-inferior to both ears) for repeated practice of Al-hijamah [103]

3.To do Al-hijamah as soon as possible after trauma (even during travel for pilgrimage and omrah before reaching the target destination) [104]

4. To practice WCT not DCT [103]

5. To practice Al-hijamah not traditional WCT [105]

6. To advise practicing Al-hijamah at days number $17^{\text {th }}$, $19^{\text {th }}, 21^{\text {st }}$ of the lunar month (in the $3^{\text {rd }}$ quarter of the lunar month) [106]

7. To advise treating headache and migraine with Alhijamah [102]

8. To attribute curative therapeutic benefits during Alhijamah to shartat mihjam (Figure 5) that is superficial (0.1 $\mathrm{m}$ in depth) skin scarifications (incisions) that are evenly distributed and confined to the skin uplifting during Alhijamah [82].

Scarifications of shartat mihjam must be preceded by the $1^{\text {st }}$ suction step and must be followed immediately by the $2^{\text {nd }}$ suction step.

To confirm the superficiality of shartat mihjam, superficial nature of shartat mihjam necessitates that the skin scarifications become multiple, small, longitudinal (1-2 mm in length), vertical and short.

In prophetic medicine, prophet Muhammad peace be upon him said: "Cure is in three: in sharata mihjam, gulp of honey and cauterization. I do not recommend my nation to cauterize" [109]

9.To attribute the curative therapeutic benefit during Alhijamah to shartat mihjam i.e. superficial (0.1 $\mathrm{m}$ in depth), small, longitudinal (1-2 mm in length), vertical and short skin scarifications confined to the skin uplifting (skin dome) during Al-hijamah [82]

10.Shartat mihjam should be superficial [82] $(0.1 \mathrm{~m}$ in depth) and longitudinal ( not pin-point needle bricks).

11.Shartat mihjam should be short skin scarifications confined to skin upliftings ${ }^{82}$ during Al-hijamah).

12.Shartat mihjam should be superficial [82] $(0.1 \mathrm{~mm}$ in depth) skin scarifications passing partially through the skin.

13.Shartat mihjam should be superficial [82] $(0.1 \mathrm{~m}$ in depth), longitudinal (1-2 $\mathrm{mm}$ in length), vertical and confined to the skin uplifting during Al-hijamah [82]

14.Shartat mihjam should be multiple and productive.
Medical, scientific and therapeutic rationale

To be as near as possible to the site of pathology for better clearance of pathology site from CPS.

Both Kahel and Akhdayin regions are remote sites for systemic blood clearance from CPS. Kahel region and points on the back of the trunk are flat and can accommodate putting many large suction cups for gaining better blood clearance induced by Alhijamah. These skin areas are hidden (better from the cosmetic point of view).

To make benefit of the analgesic effects of Al-hijamah $[2,3,16]$ and to guard against secondary bacterial infection or complications of hematoma at the site of trauma [7]

DCT has no excretory benefit while WCT clears blood from CPS [2,3,16].

Al-hijamah is a two-step filtration process (causing better blood clearance) while traditional WCT is a one-step filtration process (less effective blood clearance) [2,3].

This agrees with modern medical reports where the $3^{\text {rd }}$ quarter of the lunar month is characterized by cyclic monthly elevations in the blood pressure due to the gravitational pull of the moon. Al-hijamah at these days improves the elevated blood pressure [83].

During attacks of headache and migraine, there is high serum levels of IL-6, [107] vasoactive substances, neuropeptides, vasoactive intestinal polypeptide and calcitonin gene-related peptide. [108] Non-specific blood clearance induced during Al-hijamah helps in restoring normal blood chemistry and homeostasis.

This confirms the excretory function of Al-hijamah. Skin scarification is the step during which skin barrier is opened artificially to excrete collected fluids inside skin uplifting to excrete CPS. Through skin scarifications, suction pressure inside cups is transmitted to around skin capillaries to induce capillary filtration. This also confirms the blood clearance function of Al-hijamah [2,3].

Shartat mihjam represents the excretory function and the clearance function during $\mathrm{Al}-$ hijamah (not found in dry cupping therapy).

N.B.

- Skin if formed of three layers: epidermis, dermis and hypodermis. Epidermis is the most superficial layer and is avascular. Uppermost layer of the epidermis is the keratinized epithelium layer (stratum corneum = horny cell layer) that is the skin barrier (only 10-20 $\mu \mathrm{m}$ ) provides the primary barrier to the percutaneous absorption of compounds as well as to water loss. Underlying the stratum corneum is the viable epidermis (50-100 $\mu \mathrm{m}$ thick), that is responsible for generation of the stratum corneum [110].

- The dermis (1-2 mm thick) is directly adjacent to the epidermis and provides the mechanical support for the skin. The dermis contains fenestrated skin capillaries that are suitable for the function of pressure-dependent filtration upon application of negative suction pressure as that done during Al-hijamah.

- Skin scarification done during Al-hijamah should be so superficial just to open the skin barrier and reach the superficial dermal capillaries

- No need to scarify the skin deeply during Al-hijamah in order not to damage the fenestrated dermal capillaries

Skin puncturing (scarification and skin wounding) is associated with the production of a significant amount of nitric oxide [111,112].

Shartat mihjam is the stimulus for nitric oxide production during Al-hijamah [2]

This is important for excretory function of Al-hijamah.82In order to obtain maximal safe openings of the skin barrier, induction of wounding effect and better endogenous production of immunostimulatory cytokines [2,3,40].

Shartat mihjam should not be long incision to avoid formation of disfiguring scars (in case of cupping malpractice)

Shartat mihjam should not be deep incision to avoid injuring superficial dermal fenestrated capillaries, to avoid disturbing filtration function and to avoid subcutaneous hemorrhage

Shartat mihjam should be longitudinal openings in skin barrier (not pin-point needle bricks or punctures that easily close) to allow for better excretory functions of Alhijamah

To allow for maximal excretory function of Al-hijamah 
15.Shartat mihjam should be confined to the skin uplifting.

16.To advise practicing Al-hijamah before eating (while the stomach is empty) and during fasting [98]

17.Combining Al-hijamah with oral honey or sea costus as recommended treatments in prophetic medicine [82]

18.To use manual suction method [105] not flame or alcohol soaked cotton burning for cupping steps in $\mathrm{Al}-$ hijamah

19.To practice Al-hijamah when symptoms of hypertension develop [115]

20.Repeatability of Al-hijamah [102,103]

21.To do Al-hijamah for preventive purposes [92]

22.To change the anatomical sites for practicing Al-hijamah according to the health indication and disease treatment. $[102,103]$

23.We learn from prophetic medicine to categorize anatomical sites for practicing Al-hijamah into local and general sites [102,103].
To make use of the analgesic (hypothetic effect) of the $1^{\text {st }}$ suction step that causes collection of fluids inside the skin uplifting beneth skin barrier. To facilitate excretion of collected and filtered fluids inside the skin uplifting.

This protects against shifting of the major part of the blood circulation to the gastrointestinal tract in full stomach and intestines during food digestion and absorption that follows eating. Performing Al-hijamah on an empty stomach ensures that the skin blood circulation is adequate for better blood clearance during Al-hijamah.

Oral honey and costus are other curative remedies recommended by prophetic medicine, especially for treating diabetes mellitus. [116] Both oral honey and costus are mentioned in the same prophetic hadeeth (sayings) with Al-hijamah. Combinatory effects of both will expand the therapeutic spectrum of Al-hijamah. Viscosity of local honey can fix sucking cups during applying them to skin surface. Honey has strong antibacterial and antibiotic effects that promote wound healing [113,114].

Manual suction method was reported to be more physiological and more reproducible (when applying sucking cups to the skin) than flame or alcohol soaked cotton burning [8]. Unlike high suction pressure with alcohol and flame methods, manual suction exerts a low to moderate suction pressure [8] (no capillary damaging effect). Cotton soaked alcohol ignition and flame method may cause skin burning during suction steps in cupping therapy.

Al-hijamah was reported to be a safe, effective and long-lasting beneficial modality of treatment for hypertension. Cyclic lunar elevations in blood pressure, [83] may harm well-known hypertensive patients, stroke patients and patients with hypertensive emergency.

For cyclic and periodic clearance of blood from CPS [2,3] and to guard against their continuous accumulation with time.

For cyclic and periodic clearance of blood from CPS and to guard against their continuous accumulation with time. To remove metabolic byproducts in a step by step manner and to protect against their continuous accumulation

To suit each disease condition and gain optimal clearance of blood and interstitial fluids.

To be as near as possible to the site of pathology for optimal local clearance effect e.g. Al-hijamah is done at head region for treating headache and at sites of traumatic pain in the thigh and the dorsal aspect of the foot.

Performing Al-hijamah at local anatomical sites ensures optimal clearance of local sites of pathology e.g. at sites of trauma. [7] Performing Al-hijamah at general sites (e.g. anatomical points in the back region) [7] ensures optimal clearance of blood from CPS. Local anatomical sites are suitable sites for clearing interstitial fluids and pathology at the local health problem while general sites e.g. kahel and akhdayin are more suitable for treating systemic illness [117]

\begin{tabular}{|c|c|c|}
\hline & Acupuncture & Al-hijamah \\
\hline Definition & $\begin{array}{l}\text { The stimulation of precisely defined skin specific } \\
\text { (acupoints) along the skin of the body involving } \\
\text { various methods e.g. the application of heat, pressure } \\
\text { or laser with penetration of thin needles to treat } \\
\text { diseases and their symptoms [118] } \\
\text { Acupuncture analgesia is apparent when the intricate } \\
\text { feeling (soreness, numbness, heaviness and } \\
\text { distension) of acupuncture in patients occurs } \\
\text { following acupuncture manipulation [119]. }\end{array}$ & $\begin{array}{l}\text { A percutaneous minor therapeutic procedure through which pressure- } \\
\text { dependent and size-dependent non-specific filtration of the blood } \\
\text { occurs through the fenestrated dermal skin capillaries. The excretory } \\
\text { function is done through clearance of blood and interstitial fluids } \\
\text { from causative pathological substances that differ from disease to } \\
\text { disease according to disease etiology and pathogenesis [2,3]. }\end{array}$ \\
\hline Body organ involved & Percutaneous procedure & Percutaneous procedure \\
\hline Origin & Traditional Chinese medicine & Arabic (Al-hijamah is wet cupping therapy of prophetic medicine) \\
\hline Practiced mainly in & China, Korea, Europe and worldwide & Arabic countries, Islamic countries and in many parts of the world \\
\hline Steps & $\begin{array}{l}\text { - Site selection of anatomical sites for cups } \\
\text { application } \\
\text { - Strict sterilization (at the beginning) } \\
\text { e.g. with alcohol. } \\
\text { - The needles are inserted (frequently with a plastic } \\
\text { guide tube). } \\
\text { - Needles may be spun, flicked or moved up and } \\
\text { down relative to the skin. }\end{array}$ & $\begin{array}{l}\text { - Site selection of anatomical sites for cups application } \\
\text { - Strict sterilization (at the beginning) } \\
\text { - Skin suction } \\
\text { - Scarification } \\
\text { - Skin suction } \\
\text { - Strict sterilization (at the end) }\end{array}$ \\
\hline $\begin{array}{l}\text { Practical } \\
\text { applications }\end{array}$ & $\begin{array}{l}\text { Used in many clinical situations including pain } \\
\text { management }{ }^{120-121} \text { addiction treatment [122] smoking } \\
\text { and alleviating symptoms of menopause [123] }\end{array}$ & $\begin{array}{l}\text { In treatment of different pain conditions e.g. low back pain, } \\
\text { hematological conditions e.g. iron overload, neuropsychiatric } \\
\text { conditions and others (Table 6) }\end{array}$ \\
\hline $\begin{array}{l}\text { Pain during the } \\
\text { treatment }\end{array}$ & $\begin{array}{l}\text { Acupuncture may be painful. So, a quick insertion of } \\
\text { the needle is recommended to decrease pain } \\
\text { sensation. A skillful acupuncturist may be able to } \\
\text { insert the needles without causing any pain [124] }\end{array}$ & $\begin{array}{l}\text { Skin scarifications during Al-hijamah may be painful (mild to } \\
\text { moderate) }\end{array}$ \\
\hline $\begin{array}{l}\text { Excretory and blood } \\
\text { clearance functions }\end{array}$ & Absent & Present \\
\hline $\begin{array}{l}\text { Shartat mihjam } \\
\text { (Figure 5) }\end{array}$ & Absent. Needle punctures are done instead & Present \\
\hline $\begin{array}{l}\text { Reported } \\
\text { therapeutic health } \\
\text { benefits }\end{array}$ & Few & Numerous (Table 4) \\
\hline $\begin{array}{l}\text { Duration of } \\
\text { treatment }\end{array}$ & $\begin{array}{l}10 \text { to } 60 \text { minutes. } \\
\text { Needles may be left in the ear for up to } 3 \text { days. }\end{array}$ & 30-60 minutes \\
\hline
\end{tabular}




\begin{tabular}{|c|c|c|}
\hline $\begin{array}{l}\text { Rationale beyond } \\
\text { therapy }\end{array}$ & $\begin{array}{l}\text { Some research studies attribute acupuncture's effects } \\
\text { to placebo effect [125]. } \\
\text { Acupuncture may reduce the pain independent of a } \\
\text { psychological impact of the needling ritual }{ }^{126}\end{array}$ & $\begin{array}{l}\text { - Non-specific clearance of blood and interstitial spaces from } \\
\text { causative pathological substances. } \\
\text { - Analgesic effect through excreting pain causing substances and } \\
\text { inflammatory mediators } \\
\text { - Tissue protective effects } \\
\text { - Anti-inflammatory, anti-allergic, anti-hypertensive, anti- } \\
\text { hyperlipidemic effects and others. } \\
\text { - Hemodynamic, hematological, hemostatic and homeostatic health } \\
\text { benefits. } \\
\text { - Other therapeutic benefits (Table 4) }\end{array}$ \\
\hline $\begin{array}{l}\text { As a treatment for } \\
\text { pain }\end{array}$ & $\begin{array}{l}\text { An overview of high-quality Cochrane reviews } \\
\text { suggested that acupuncture is effective for some but } \\
\text { not all kinds of pain [127] }\end{array}$ & $\begin{array}{l}\text { Proved effective in treating different types and intensities of pain } \\
{[2,3]}\end{array}$ \\
\hline $\begin{array}{l}\text { Etiology of the } \\
\text { analgesic effect }\end{array}$ & $\begin{array}{l}\text { - May be due to interaction of the afferent impulses } \\
\text { from pain regions with those from the point of } \\
\text { acupuncture [128] } \\
\text { - May be caused by the release of endorphins } \\
\text { - Endog,130] } \\
\text { acupuncture opiate peptides may participate in } \\
\text { the receptor sites [131]. } \\
\text { - Needling of the acupuncture point could activate } \\
\text { the afferent fibers of peripheral nerves through the } \\
\text { ventro-lateral funiculi (conducting pain and } \\
\text { temperature sensation) upward to the brain and } \\
\text { activate the antinociceptive system } \\
\text { - Many brain nuclei may process acupuncture } \\
\text { analgesia e.g. the nucleus raphe magnus, } \\
\text { periaqueductal grey, locus coeruleus, arcuate } \\
\text { nucleus, preoptic area, nucleus submedius, } \\
\text { habenular nucleus, accumbens nucleus, caudate } \\
\text { nucleus, septal area, amygdale and others [119]. }\end{array}$ & $\begin{array}{l}\text { - Through correcting disease etiopathogenesis } \\
\text { - Through excreting pain-causing substances e.g. inflammatory } \\
\text { mediators } \\
\text { - Through bathing nerve endings in collected fluids beneath skin } \\
\text { barrier (decreases transmission of pain signals) }[2,3] \\
\text { - Through stimulating the release of endogenous opioids }\end{array}$ \\
\hline Safety & $\begin{array}{l}\text { - Acupuncture is generally safe when administered } \\
\text { using the clean needle technique but there is a low } \\
\text { risk of adverse effects, which can be serious [84] } \\
\text { including death in rare cases [125]. }\end{array}$ & $\begin{array}{l}\text { Generally safe when practiced properly. Some side effects may be } \\
\text { encountered e.g. Taibah sign, skin bruises and bleeding. }\end{array}$ \\
\hline Contraindications & $\begin{array}{l}\text { No absolute contraindications for acupuncture [132]. } \\
\text { Relative contraindications include: } \\
\text { High risk pregnancy } \\
\text { Infants with open fontanelles } \\
\text { Acupoints near eyeball (with beginners) }\end{array}$ & $\begin{array}{l}\text { No absolute contraindications for Al-hijamah } \\
\text { Relative contraindications include: } \\
\text { - Severe anemia } \\
\text { - Conditions of active bleeding } \\
\text { - Circulatory failure (shock) } \\
\text { - Recent burn (inflamed tissues) } \\
\text { - High risk pregnancy } \\
\text { - Near the course of superficial nerves and vessels (for fear of nerve } \\
\text { injury or bleeding. In these cases, careful study of the anatomical } \\
\text { sites should be revised and Salah’s technique for safe practice } \\
\text { should be applied) [7]. }\end{array}$ \\
\hline Precautions & $\begin{array}{l}\text { - For pregnant women, avoid needling points on the } \\
\text { abdomen and lumbar region } \\
\text { - Avoid points on the scalps of infants with open } \\
\text { fontanelles } \\
\text { - Needling points close to the eyeball requires } \\
\text { definite angle, depth, and skill } \\
\text { - Avoid deep perpendicular penetration of acupoints } \\
\text { on the thoracic and lumbar regions due to risk of } \\
\text { puncturing internal organs } \\
\text { - Avoid deep and perpendicular penetration of points } \\
\text { around the gastric cavity when the stomach is full } \\
\text { - Deep penetration of gallbladder } 21 \text { puts patients at } \\
\text { risk of pneumothorax } \\
\text { - Avoid deep penetration of points at the base of the } \\
\text { skull inferior to the occiput (gallbladder 20, } \\
\text { ren/governing vessel } 16 \text {, and bladder 10) due to } \\
\text { risk of injuring the medulla oblongata [132]. }\end{array}$ & $\begin{array}{l}\text { - Strict sterilization is a must throughout the whole procedure } \\
\text { - Anatomical sites for cups application must be specified accurately } \\
\text { - Moderate suction pressure inside cups for } 5 \text { minutes is the best } \\
\text { - Use Salah's technique for safe practice at specific anatomical sites } \\
\text { [7] }\end{array}$ \\
\hline Side effects & $\begin{array}{l}\text { - } \text { Bacterial infection [84]. } \\
\text { - Spinal cord injuries (e.g. migrating broken needles } \\
\text { or needling too deeply) } \\
\text { - Bilateral hand edema } \\
\text { - Epithelioid granuloma } \\
\text { - Pseudolymphoma } \\
\text { - Argyria } \\
\text { - Pustules } \\
\text { - Pancytopenia } \\
\text { - Scarring due to hot needle technique [84]. } \\
\text { - Syncope } \\
\text { - Galactorrhoea }\end{array}$ & $\begin{array}{l}\text { - Few side effects are attributed to Al-hijamah e.g. Taibah sign } \\
\text { (Figure 4). There is almost no side effect when Al-hijamah is } \\
\text { practiced properly. } \\
\text { - Reported side effects are mainly related to malpractice e.g. } \\
\text { prolonged suction time ( }>10 \text { minutes) and excessive suction } \\
\text { pressure ( }>-300 \mathrm{mmHg} \text { in dry cupping therapy or deep } \\
\text { scarifications (more than } 0.5 \mathrm{~mm} \text { in depth) in wet cupping therapy. } \\
\text { - Reported minor side effects of cupping therapy are keloid scarring, } \\
\text { burns and bullae [84]. } \\
\text { - Serious side effects are very rare and were reported to be attributed } \\
\text { to traditional WCT e.g. acquired hemophilia A, stroke following }\end{array}$ \\
\hline
\end{tabular}




\begin{tabular}{|c|c|c|}
\hline & $\begin{array}{l}\text { - Bilateral nystagmus } \\
\text { - Pyoderma gangrenosum } \\
\text { - Hepatotoxicity } \\
\text { - Eruptive lichen planus [84] } \\
\text { - Local skin irritation } \\
\text { - Convulsions } \\
\text { - Psychiatric disturbance } \\
\text { - Headaches } \\
\text { - Sweating } \\
\text { - Dizziness } \\
\text { - Aggravation of symptoms }\end{array}$ & $\begin{array}{l}\text { cupping on the back and neck, factitious panniculitis, reversible } \\
\text { cardiac hypertrophy and iron deficiency anemia [84]. }\end{array}$ \\
\hline Complications & $\begin{array}{l}\text { Pneumothorax, spinal cord injury, punctured organs, } \\
\text { bruising, needle breakage, septicemia }\end{array}$ & Bleeding, infection and ecchymosis (signs of malpractice) \\
\hline Equipment & $\begin{array}{l}\text { Acupuncture needles are disposable and are typically } \\
\text { made of stainless steel to prevent them from rusting, } \\
\text { breaking, and making them flexible 133]. } \\
\text { Reusable needles must be sterilized before use [134] }\end{array}$ & Disposable equipment (plastic cups and hand-held pump) \\
\hline Cost-effectiveness & Cost-effective (ranging from $\$ 25$ to $\$ 80$ ) [135]. & Cost-effective (about 10-20\$ per session) \\
\hline Disease indications & $\begin{array}{l}\text { Pain conditions, pain of shoulder and elbow, } \\
\text { peripheral osteoarthritis, headache and migraine, low } \\
\text { back pain, fibromyalgia, Parkinson's disease and } \\
\text { others. }\end{array}$ & $\begin{array}{l}\text { - Msculoskeletal pain conditions } \\
\text { - Hematological conditions e.g. hemolysis and iron overload } \\
\text { - Cardiovascular diseases e.g. hypertension } \\
\text { - Inborn errors of metabolism e.g. galactosemia } \\
\text { - Some dermatological conditions e.g. urticaria } \\
\text { - Neuropsychiatric diseases e.g. headache } \\
\text { - Malignancy } \\
\text { - Metabolic conditions e.g. gout } \\
\text { - Infections e.g. viral hepatitis } \\
\text { - Respiratory and ENT diseases e.g. asthma } \\
\text { - Autoimmune diseases e.g. rheumatoid arthritis } \\
\text { - Gastrointestinal diseases e.g. irritable bowel syndrome } \\
\text { - Heavy metal intoxication } \\
\text { - Drug overdosage }\end{array}$ \\
\hline Popularity & $\begin{array}{l}\text { Popular among people seeking for complementary } \\
\text { and alternative medicine. } \\
\text { In USA, about } 16 \% \text { of people seeking for } \\
\text { complementary and alternative medicine used } \\
\text { acupuncture [136]. } \\
\text { Family physicians use acupuncture for pain } \\
\text { management of musculoskeletal conditions, [137] for } \\
\text { cancer treatment, [138] and for postoperative } \\
\text { conditions [139,140]. }\end{array}$ & $\begin{array}{l}\text { Popular in the middle east, Arabic world, Some parts of Europe and } \\
\text { Asia. }\end{array}$ \\
\hline $\begin{array}{l}\text { Popularity in } \\
\text { western world }\end{array}$ & $\begin{array}{l}\text { According to the British Medical Acupuncture } \\
\text { Society, [141] health care providers e.g. licensed } \\
\text { acupuncturists, chiropractors, naturopaths, and } \\
\text { physiotherapists practice acupuncture. } \\
\text { Three provinces in Canada regulate acupuncture: } \\
\text { Alberta, British Columbia, and Quebec. } \\
\end{array}$ & $\begin{array}{l}\text { Practiced by immigrants and eastern communities and minorities in } \\
\text { the western world }\end{array}$ \\
\hline
\end{tabular}

\section{Indications and Rationales for Practicing Al-hijamah}

The most important point as regard indications for practicing Al-hijamah is to understand steps of disease pathogenesis. The first question to be asked is what is the disease pathology and what are the CPS that are implicated in causing the disease process or result during its pathogenesis and to what extent does their levels increase in patient's serum or locally at the sites of pathology?

As a golden rule, Al-hijamah is indicated whenever disease etiology and pathogenesis will improve and become corrected partially or totally from blood clearance, interstitial fluid clearance, excreting disease CPS and normalizing blood chemistry. Examples of disease conditions that may benefit from excreting excess fluids are hypertension, vascular congestion, circulatory overload and edema (whatever the etiology). Examples of diseases that may benefit from excreting excess solutes e.g. high serum iron and serum ferritin in conditions of iron overload e.g. thalassemia, sideroblastic anemia, bronze diabetes, hemosiderosis and hemochromatosis. [49,50] In addition, common CPS for all autoimmune diseases include high serum autoantibodies, immune complexes and inflammatory mediators. [51,52] CPS for viral infections include high serum levels of virus particles (having sizes in nanometer range), viral antigens and inflammatory mediators. [53] CPS for bacterial infections may include high serum levels of bacteria (bacteremia) and bacterial toxins (toxemia) causing secondary septicemia and septic shock. [54] CPS for musculoskeletal pain conditions include high serum and or local interstitial fluid levels of inflammatory mediators, prostaglandins, certain cytokines and pain-causing substances e.g. substance P. [55,56] CPS for metabolic diseases include high serum levels of accumulated substrates and secondary metabolic products that may disturb organ functions. [57] CPS for hormonal imbalance e.g. endocrine hyperfunction conditions may include high serum level of hormones and or their releasing hormones, which causes secondary metabolic effects e.g. hyperestrogenemia is an etiological factor for ovulatory dysfunction causing secondary female infertility. [58] CPS for cardiovascular disorders may include hyperlipidemia and hypercholesterolemia causing secondary atherosclerosis and hypertension. [59] CPS for addiction, suicidal tendencies using drugs and drug intoxication e.g. 
alcoholism may include high serum levels of causative drugs with secondary metabolic deteriorations. [60] CPS for some neurological conditions may include high serum levels of causative chemical substances (DCS or DRS), inflammatory mediators, cytokines and prostaglandins. [61] For cancer patients, CPS may include high serum growth factors produced by cancer cells to facilitate malignant cell survival, progression, angiogenesis and metastasis. CPS in serum of cancer patients may include also high serum lactate dehydrogenase, lactate (Warburg effect) and tumor markers. Lactate is a metabolic key player in cancer [62] and is reported to the mirror and motor of malignancy. [63] We and Japanese coresearchers reported that antagonizing the effects of lactate and pyruvate (through using the lactate analog, 3bromopyruvate) killed cancer cells (glioblastoma multiforme cells), delayed their metastasis, [64] inhibited angiogenesis, [65] depleted tumor energetics, induced oxidative stress in cancer cells [66], inactivated ABC transporters (that excrete cancer chemotherapeutics) and restored drug sensitivity in malignant cells. [67] Recently, we reported that lactate produced in cancer cells (Warburg effect) increases steady-state ROS condition in cancer cells through decreasing their antioxidant capacities [68]. Al-hijamah may be beneficial for cancer patients to clear blood from those CPS (lactate, lactate dehydrogenase, cancer growth factors, metastatic growth factors and others), enhance natural immunity (anticancer effect), decrease tumor interstitial fluid pressure (an earlyresponse marker for anticancer therapeutics [69] and potentiate therapeutic effect of chemotherapy. Clearing blood of cancer patients from lactate (Warburg effect) may deprive cancer cells from all lactate-based benefits as regard cancer cell survival, proliferation, metastasis, adhesion, invasion, angiogenesis and others. NO (endogenously produced during Al-hijamah) acts as an antiproliferative, anti-leukemia and antineoplastic agent [70].

As a golden rule, Al-hijamah is a beneficial and curative but never harmful. Degree of therapeutic benefits gained after Al-hijamah depends on the degree of response and improvement of disease pathogenesis in response to the serum clearing effect of Al-hijamah taking into account the other therapeutic benefits exerted by Alhijamah (Table 4). Other important factors that govern the therapeutic outcomes of Al-hijamah are the skills of the practitioner (better to be physicians specialized in Alhijamah, plastic surgeons, dermatologists or any other interested qualified licensed physicians and non-medical practitioners), number of cups, duration of cups application, optimizing suction pressure, combination with pharmacological treatment and also selecting the proper anatomical sites for cups application. Proper practice of shartat mihjam (Table 7) (Figure 5A-C) as we learnt from prophetic medicine is essential to optimize the therapeutic results of Al-hijamah. Compared with acupuncture as a traditional Chinese medicine, acupuncture needs skills for practice with some similarities and differences with Alhijamah (Table 8).

\section{Therapeutic Benefits of Al-hijamah for Diabetic and Stroke Patients}

Although it was reported that the evidence for therapeutic benefits of cupping therapy as regard stroke rehabilitation is minimal, [11] this may not be applied to Al-hijamah, which has many therapeutic aspects (more than traditional DCT and WCT) that are closely related to stroke treatment in those patients. The therapeutic benefits of Al-hijamah may treat disease conditions commonly associated with stroke e.g. hypertension, hyperlipidemia, atherosclerosis [1] and may improve circulation [2,3] e.g. to paralyzed limbs. Stroke patients are usually maintained on a long list of drugs that treat predisposing factors for stroke, especially hypertension, diabetes mellitus, hyperlipidemia, [71] vascular thrombosis (antiplatelet and anticoagulants in cerebral infarction), [72] and others. Treating the above-mentioned predisposing factors (Table 6) is as important as physiotherapy to the paralyzed muscles due to the effect of stroke. Blood clearance effect induced by Al-hijamah was reported to reduce blood pressure and improve lipid profile, [1] which is expected to delay occurrence and progression of atherosclerosis (cerebral stroke is mainly a vascular disease). Al-hijamah may potentiate the therapeutic effects of antihypertensive and anti-hyperlipidemic drugs (drug potentiation effect) [2] and may decrease the possibility of pharmacological interactions and antagonism that may occur when many drugs are simultaneously administered. In addition, Alhijamah may decrease the economic and financial burden upon the patient and health insurance if we could decrease the dose or frequency of concomitant drug administration. Moreover, cupping therapy (e.g. Al-hijamah) decreases vascular congestion, improves microcirculation, treats peripheral ischemia and may have a physiotherapy effect. $[2,3]$ Some superior effects of cupping were reported in some randomized controlled trials (compared to acupuncture) in treating hemiplegic shoulder pain and high upper-limb myodynamia after stroke. Favorable effects of cupping on aphasia and intractable hiccup after stroke were also reported [73].

As diabetes mellitus is a common association with cerebrovascular stroke, Al-hijamah may benefit patients having both diabetes and stroke despite being non-curative to diabetes mellitus itself. Al-hijamah was recently reported to decrease serum ferritin in health subjects (predisposing factor to diabetes mellitus). [1] It was recently reported that there is a significant association between high serum lipids and ferritin with the progression to insulin resistance (in type I and type II diabetes), which indicates a greater risk of micro- and macrovascular disease in diabetic patients [74,75,76].

Interestingly, Iron depletion improves vascular dysfunction in type-2 diabetic patients with high ferritin concentrations. [77] Hyperferritinemia may be an independent risk factor of microalbuminuria in diabetic nephropathy in patients with Type-2 diabetes. [78] Bloodletting was reported to decrease serum glycosylated hemoglobin (HbA1c) levels, to induce statistically significant increase in insulin sensitivity and to induce improvements in insulin secretion and insulin resistance that were significantly different from subjects with highferritin type-2 diabetes. [79] Based on that, Al-hijamahinduced non-specific pressure-dependent filtration of blood, clearance of serum ferritin and bloodletting seem to be so beneficial to guard against the development of 
diabetes mellitus and to treat diabetic patients (type 1 and type-2 diabetes).

Importantly, uncontrolled hyperglycemia in diabetic patients may activate the polyol pathway in which persistently high serum glucose (in uncontrolled hyperglycemia) may be converted to sorbitol (has osmotic damaging effect), may cause generation of free radicals and may induce the formation of advanced glycation end products. All those may collectively cause damage to the nerve cells and vascular endothelial cells i.e. predispose to diabetic angiopathy, neuropathy and nephropathy. [80] Unfortunately, blood chemistry of diabetic patients (uncontrolled hyperglycemia) may exhibit high serum advanced glycation end products, free radicals, metabolites of abnormal metabolism of carbohydrates and lipids (due to insulin lack), high serum cholesterol, high serum LDL and others. [80] Based on that, non-specific serum clearance induced by Al-hijamah may protect against and prevent further progression of some long-term complications of diabetes mellitus. Al-hijamah may benefit diabetic patients; prolong disease-free survival and offer better treatment outcomes. It should be considered that other therapeutic benefits of Al-hijamah e.g. enhancing immunity, neurological benefit, hemostatic benefit, homeostatic benefit and others (Table 4) may improve the general condition of diabetic and stroke patients.

Interestingly, Al-hijamah may confer some therapeutic benefits similar to that exerted by many drugs e.g. vasodilator effect (Al-hijamah treats ischemia through release of NO), [2,12,13] antihypertensive effect (Alhijamah decreases both systolic and diastolic blood pressure), [1] hypolipidemic effect (Al-hijamah decreases serum triglycerides, total cholesterol and LDL-cholesterol) [1], immunostimulant effect (Al-hijamah enhances natural immunity), [16] iron-lowering effect (Al-hijamah reduces serum ferritin [1] while excessive WCT causes iron deficiency), [20,21,47] excretory effect to bacteria and toxins in blood (CT treats cellulitis), [17] analgesic effect (treats headache, migraine [35] and releases endogenous opioids), [2,3] angiogenic effect (improves capillary circulation), [2,3] urate clearance effect (Al-hijamah reduced uric acid), [1] anti-neoplastic effect (Al-hijamah clears blood chemistry of cancer patients from growth factors and cancer-related products in addition to the role of released NO). [2,3,70] Interestingly, there is no chance for occurrence of antagonism among those pharmacological effects of Al-hijamah with different pharmacological treatments as Al-hijamah is a mechanical procedure where no chemical interaction will develop.

\section{Lessons gained from prophetic medicine regarding timing and practice of Al-hijamah}

Prophetic medicine (related to Prophet Muhammad peace be upon him) recommends Al-hijamah: “The best among what you use in therapy is Al-hijamah (prophetic method of cupping therapy)" [81] and "If there is a benefit in any of your treatment modalities, benefit will be in shartat mihjam, a gulp of honey and cauterizing, but I do not like cauterization". [82] Recently, Loukas et al. reported that knowledge gained from studying the Qur'an (spoken word of God) and Hadeeth (spoken word of Prophet Muhammad peace be upon him) enabled a good comprehension of studying some parts of the human body e.g. the heart and cardiovascular system. They reported also that remedies mentioned in prophetic medicine have agreement with modern medical knowledge. [6] When reviewing prophetic medicine as regard the practice of Alhijamah, we can get the most important lessons regarding the procedure (shartat mihjam) (Figure 5), anatomical sites, timing and indications of Al-hijamah. We can learn also and associated treatments to be used with Al-hijamah e.g. oral honey, costus and others. In prophetic medicine, Alhijamah is recommended in days number $17^{\text {th }}, 19^{\text {th }}, 21^{\text {st }}$ of the lunar month (during the third quarter of the lunar month). This agrees with modern medical reports where the gravitational pull of the moon was recently reported to affect the cardiovascular functions of the human body. In healthy subjects, both systolic blood pressure (BP) and mean arterial BP were about $5 \mathrm{mmHg}$ higher in the third quarter of the lunar month $\left(15^{\text {th }}-21^{\text {th }}\right.$ day of the lunar month). Physical fitness index was also lower in the third and fourth quarters of lunar month. [83] Performing Alhijamah regularly at the $3^{\text {rd }}$ quarter of the lunar month may help treating the cyclic elevations in blood pressure that usually occur.

\section{Side Effects and Safety Issues during Al-hijamah}

Among the most important parameters when evaluating a therapeutic modality e.g. Al-hijamah is the safety issue and side effects. With regard to Al-hijamah, it is rare to encounter a side effect when the criteria for proper practice are fulfilled as we discussed in shartat mihjam (Table 7) (Figure 5). The patient must be a good candidate for Al-hijamah i.e. hemodynamically stable and with no uncontrolled bleeding or uncontrolled coagulation disorders. It is contraindicated to perform Al-hijamah in a shocked patient, severely anemic patient or in case of a recent burn with inflamed sites for cups application. However, after the acute condition improves, reevaluation of the patient's general condition is needed before practicing Al-hijamah where the risk/benefit ratio should be applied. Strict sterilization is a must during the whole procedure. The triple S steps (suction, scarification and suction) of Al-hijamah should be optimized. Suction should be manual using a hand-held pump (not cotton or alcohol ignition to avoid skin burns). Suction time should be 5 minutes while suction pressure should be moderate (4 maximal suction times using the hand-held pump). Shartat mihjam (Figure 5) should be superficial skin scarifications (0.1 mm in depth) confined to the skin uplifting. Shartat mihjam should be multiple, longitudinal (1-2 mm), equally distributed and productive skin scarifications. Practitioner's skill is to do shartat mihjam rapidly to get the maximal non-specific clearance benefit induced by Alhijamah. Any violation from these criteria is regarded as a malpractice and is expected to carry side effects.

Reported side effects were related to the malpractice of cupping therapy (traditional DCT and traditional WCT) not Al-hijamah. However, as the cupping methodology is similar in both, reported side effects should be considered and should be divided into common and rare side effects. 
Common side effects include bleeding (due to deep long scarification), skin bruises (due to excessive suction pressure or prolonged suction duration causing dermal capillary rupture), keloid scarring and burns (when method of suction is cotton or alcohol ignition). [84] The rare serious side effects include acquired hemophilia A (in one patient after traditional Chinese WCT due to extensive bruising which led to pending compartment syndrome of patient's left thigh 2 days after cupping with excessive bleeding) [85].

Cupping of the cervical area in an individual case resulted in a hemorrhagic stroke caused by an acute rise in blood pressure. Other side effects due to malpractice included factitious panniculitis (in one patient who underwent traditional WCT while traveling in an airplane), reversible cardiac hypertrophy, and iron deficiency anemia (due to too frequent sessions of traditional WCT with extensive bleeding by an unqualified practitioner) [21].

\section{Future of Al-hijamah}

Future of Al-hijamah is promising as a vital modality of treatment directed towards clearing serum and interstitial fluids from CPS to restore physiological homeostasis. Alhijamah carries a lot of hope in improving the therapeutic outcomes of a large number of diseases that are still of dismal prognosis. Future scientific research and published research studies are vital to put Al-hijamah in its proper position as a simple, curative and economic modality of treatment.

The early Islamic medical scholars were pioneering in practicing, teaching and writing about Al-hijamah in their medical books e.g. Al-Qanon Fi Al-Tib (The law in medicine), which is a big textbook in medicine and surgery that was written by Avicenna (Ibn Sina). That book was among the main references to humanity medicine since the beginning of XI century until the middle of XIII century. With Al-Qanon, the golden age of the Arabic medicine came to its peak. [86,87] Avicenna described in this great textbook many details about using Al-hijamah in treating different diseases. [88,89] Alhijamah is now an international evidence-based medicine available for patients, hospitals, research institutions and academics worldwide for more fruitful research and investigation. Al-hijamah is not secluded to the Arabic patients or Arabic medicine. Lack of proper understanding of how Al-hijamah treats a diverse spectrum of diseases differing in etiology and pathogeneses played an important role in delaying practicing Al-hijamah as a standard official line of treatment worldwide. Taibah mechanism (Taibah theory) for scientific bases of Alhijamah and cupping therapy explained on medical bases the detailed mechanisms of action of Al-hijamah and differentiated it from other types of cupping therapy [2,3].

We appreciate so much that cupping therapy is practiced officially in Chinese hospitals and in some European countries. We appreciate that Al-hijamah is practiced officially in hospitals in the United Arab Emirates. We appreciate also the fruitful efforts exerted by the Saudi Mministry of Health and the National Center for Complementary and Alternative Medicine in introducing the medical education and continuous medical training on Al-hijamah as an evidence-based medicine taking into account gaining maximum benefits of the international experience in cupping therapy to optimize and standardize the practice of Al-hijamah by qualified practitioners. The Saudi National Center for Complementary and Alternative Medicine is carrying active research projects and clinical trials for treating different diseases using Al-hijamah in the official governmental hospitals in a pure medical atmosphere in Saudi Arabia (homeland of Al-hijamah and prophetic medicine) where Al-hijamah is performed by qualified well-trained and licensed physicians who got a practice license from the Saudi Commission for Health Specialties (SCFHS).

We appreciate so much the research efforts exerted by the scientific chair of prophetic medicine in Taibah University (supervised by professor Bassim Y. Sheikh) in Al-Madinah, Saudi Arabia where a well-equipped clinic for practicing Al-hijamah according to the highest academic standards was already established and is providing the health benefits for treating patients using Alhijamah. Al-hijamah clinic in Taibah University is carrying out active research projects to meticulously endeavor and to unravel the medical and health benefits of Al-hijamah at myriad specialties. Moreover, the scientific chair of prophetic medicine in Taibah University had a big participation and fruitful research results in investigating the therapeutic benefits of natural remedies of prophetic medicine as ajwa of Aliah (date fruit of Al-madinah). [90] and nigella sativa [91].

\section{Research Recommendation}

It is highly recommended to encourage the practice of Al-hijamah in hospitals in a pure medical atmosphere. The anti-diabetic effects of Al-hijamah e.g. blood clearance effects from high circulating iron stores (ferritin), abnormal lipid profile, advanced glycation end products, glycosylated serum proteins and others makes it an essential line of treatment for both preventive and therapeutic purposes in agreement with the teachings of the Prophet Muhammad peace be upon him. Currently, modern societies e.g. in the western world and in Arabic countries are characterized a sedentary life style in which physical exercise e.g. walking is minimal and dependence on the welfare transportation facilities is the rule. This may facilitate the development of some diseases e.g. obesity, insulin resistance, diabetes, hyperlipidemia, atherosclerosis, hypertension, stroke and others. Moreover, daily western diet is composed of a high content of sugars, carbohydrates and saturated lipids, which may cause a diabetogenic effect. Based on that, Al-hijamah seems to be a vital and essential modality of treatment in our Arabic societies.

\section{Conclusion}

Al-hijamah (WCT of prophetic medicine) may be a promising treatment for increasing immunity of human body, potentiating pharmacological effects of modern drugs and clearing blood from pathological substances causing and related to pathogenesis of many diseases.

\section{Conflict of Interest}

The authors declare that there is no conflict of interest. 


\section{Acknowledgement}

Our sincere thanking is offered to the helpful revisions, nice additions and corrections made by Dr. Jameel Awwad Sulami, (H.D., Researcher \& Consultant in Prophetic Medicine, Doctor of Hijamatology, Holistic and Functional Medicine Specialist from Turkey). Efforts of Dr. Jameel deserve appraisal in honestly serving prophetic medicine. Indeed, Dr. Jameel offered big efforts as an advisor for this work. We are so grateful to the library of Sohag faculty of medicine, Sohag University, Egypt for providing the internet facility and helpful textbooks.

\section{List of Abbreviations}

$\begin{array}{ll}\text { DCS } & \text { Disease-causing substances } \\ \text { DCT } & \text { Dry cupping therapy } \\ \text { DRS } & \text { Disease-related substances } \\ \text { RA } & \text { Rheumatoid arthritis } \\ \text { SS method } & \text { Suction and scarification method } \\ \text { SSS method } & \text { Suction, scarification and suction } \\ \text { WCT } & \text { Wet cupping therapy }\end{array}$

\section{References}

[1] Alshowafi FK. Effect of Blood Cupping on Some Biochemical Parameter. Med. J. Cairo Univ. 2010; 78: 311-315.

[2] El Sayed SM, Mahmoud HS and Nabo MMH. Medical and scientific bases of Wet Cupping Therapy (Al-Hijamah): In Light of Modern Medicine and Prophetic Medicine. Altern Integ Med. 2013; 2: 1-16.

[3] El Sayed SM, Mahmoud HS and Nabo MMH. Methods of Wet Cupping Therapy (Al-Hijamah): In Light of Modern Medicine and Prophetic Medicine. Altern Integ Med. 2013; 2: 1-16.

[4] Huang YL.Cupping-bloodletting therapy of Saudi Arabia and its clinical application. Zhongguo Zhen Jiu.2008; 28: 375-377.

[5] Al-Jauziyah IIQ. Prophetic Medicine (Healing with the Medicine of the Prophet Peace be upon Him). Fordham University: Darussalam Publishers \& Distributors. 1999. Translated by Jalal Abual Rub.

[6] Loukas M, Saad Y, Tubbs RS, Shoja MM. The heart and cardiovascular system in the Qur'an and Hadeeth. Int J Cardiol. 2010; 140: 19-23.

[7] Mahmoud HS, Abou-El-Naga M, Omar NAA, El-Ghazzawy HA, Fathy YM, Nabo MMH et al. Anatomical sites for practicing Wet Cupping Therapy (Al-Hijamah): In Light of Modern Medicine and Prophetic Medicine. Altern Integ Med 2013; In press.

[8] Huber R, Emerich M, Braeunig M. Cupping-is it reproducible? Experiments about factors determining the vacuum. Complement Ther Med. 2011; 19: 78-83.

[9] Kanitakis J. Anatomy, histology and immunohistochemistry of normal human skin. Eur J Dermatol. 2002; 12: 390-9.

[10] Sarin H. Physiologic upper limits of pore size of different blood capillary types and another perspective on the dual pore theory of microvascular permeability. J Angiogenes Res. 2010; 2: 14.

[11] AlBedah A, Khalil M, Elolemy A, Elsubai I, Khalil A. Hijama (cupping): a review of the evidence. Article first published online: Fact. 2011; 16: 12-16

[12] Cals-Grierson MM, Ormerod AD. Nitric oxide function in the skin. Nitric Oxide. 2004; 10: 179-93.

[13] Schäffer MR, Tantry U, van Wesep RA, Barbul A. Nitric oxide metabolism in wounds. J Surg Res 1997; 71: 25-31.

[14] Fok H, Jiang B, Clapp B, Chowienczyk P. Regulation of vascular tone and pulse wave velocity in human muscular conduit arteries: selective effects of nitric oxide donors to dilate muscular arteries relative to resistance vessels. Hypertension. 2012; 60: 1220-5.

[15] Ahmadi A, Schwebel DC, Rezaei M. The efficacy of wet-cupping in the treatment of tension and migraine headache. Am J Chin Med. 2008; 36: 37-44.

[16] Ahmed SM, Madbouly NH, Maklad SS, Abu-Shady EA. Immunomodulatory effects of bloodletting cupping therapy in patients with rheumatoid arthritis. Egypt J Immunol. 2005;12:3951.

[17] Ahmed A, Khan RA, Ali AA, Ahmed M, Mesaik MA. Effect of wet cupping therapy on virulent cellulitis secondary to honey bee sting-a case report. Journal of Basic and Applied Sciences. 2011; 7: 123-125.

[18] Farahmand SK, Gang LZ, Saghebi SA, Mohammadi M, Mohammadi S, Mohammadi G, et al. The effects of wet cupping on coronary risk factors in patients with metabolic syndrome: a randomized controlled trial.Am J Chin Med. 2012; 40: 269-77.

[19] Bilal M, Khan RA, Ahmed A, Afroz A (2011) Partial evaluation of technique used in cupping therapy. Journal of Basic and Applied Sciences 7: 65-68.

[20] Sohn IS, Jin ES, Cho JM, Kim CJ, Bae JH, Moon JY et al. Bloodletting-induced cardiomyopathy: reversible cardiac hypertrophy in severe chronic anaemia from long-term bloodletting with cupping. Eur J Echocardiogr. 2008; 9: 585-6.

[21] Kim KH, Kim TH, Hwangbo M, Yang GY. Anaemia and skin pigmentation after excessive cupping therapy by an unqualified therapist in Korea: a case report. Acupunct Med. 2012; 30: 227-8.

[22] Al-Saedy SA, El-Hazemy MA, Hassan MI, Badawy AS, Bahr MH. Studying molecular biology of Al-hijamah in patients with hepatitis C infection (In Arabic). Al-Ijaz Al-Ilmy (Scientific miracle). 2007; 27: 28-37.

[23] Badawy AE, El-Hazemy. Al-hijamah (a scientific perspective) (In Arabic). Al-Sunnah library. Cairo, Egypt. 2007: 49-59.

[24] Abd al-Jawad MEM, Mohamed SA, Elsayed BA, Mohamed ANM. Evaluation of Wet Cupping Therapy (Hijama) as an Adjuvant Therapy in the Management of Bronchial Asthma. Indian Journal of Physiotherapy and Occupational Therapy - An International Journal. 2011; 5: 122-126.

[25] Lauche R, Langhorst J, Dobos GJ, Cramer H. Clinically meaningful differences in pain, disability and quality of life for chronic nonspecific neck pain - A reanalysis of 4 randomized controlled trials of cupping therapy. Complement Ther Med. 2013; 21: 342-7.

[26] Cao H, Li X, Liu J (2012) An updated review of the efficacy of cupping therapy. PLoS One 7: e31793.

[27] Lüdtke R, Albrecht U, Stange R, Uehleke B. Brachialgia paraesthetica nocturna can be relieved by "wet cupping"--results of a randomised pilot study. Complement Ther Med. 2006;14: 247-253.

[28] Last AR, Hulbert K. Chronic low back pain: evaluation and management. Am Fam Physician. 2009; 79: 1067-1074.

[29] Zhang HL. Blood-letting puncture and cupping therapies combined with acupuncture for treatment of 140 cases of fibrositis. J Tradit Chin Med. 2009; 29: 277-278.

[30] Cao H, Hu H, Colagiuri B, Liu J. Medicinal cupping therapy in 30 patients with fibromyalgia: a case series observation. Forsch Komplementmed 2011; 18: 122- 126.

[31] Kim JI, Kim TH, Lee MS, Kang JW, Kim KH, Choi JY et al. Evaluation of wet cupping therapy for persistent non-specific low back pain: a randomised, waiting-list controlled, open-label, parallel-group pilot trial. Trials; 12: 146-152.

[32] Teut M, Kaiser S, Ortiz M, Roll S, Binting S, et al. (2012). Pulsatile dry cupping in patients with osteoarthritis of the knee-a randomized controlled exploratory trial. BMC Complement Altern Med. 2012; 12: 184-192.

[33] Sultana A, Ur Rahman K, Farzana M, Lone A. Efficacy of hijamat bila shurt (dry cupping) on intensity of pain in dysmenorrhoea-a preliminary study. Anc Sci Life. 2012; 30: 47-50.

[34] Zhang SJ, Liu JP, He KQ. Treatment of acute gouty arthritis by blood-letting cupping plus herbal medicine. J Tradit Chin Med. 2010; 30: 18-20.

[35] El Sayed SM, Abou-Taleb A, Mahmoud HS, Ahmed NS, Nabo MM Percutaneous excretion of iron (through Al-hijamah) as a novel treatment to iron overload in beta-thalassemia major, hemochromatosis and sideroblastic anemia. Med Hypothes 2013 In press.

[36] Zhang Z. Observation on therapeutic effects of blood-letting puncture with cupping in acute trigeminal neuralgia. J Tradit Chin Med. 1997; 17: 272-274.

[37] Michalsen A, Bock S, Lüdtke R, Rampp T, Baecker M, et al. Effects of traditional cupping therapy in patients with carpal tunnel syndrome: a randomized controlled trial. J Pain. 2009; 10: 601-608.

[38] Niasari M, Kosari F, Ahmadi A. The effect of wet cupping on serum lipid concentrations of clinically healthy young men: a 
randomized controlled trial. J Altern Complement Med. 2007; 13: 79-82.

[39] Zhang C. Treatment of 31 cases of allergic rhinitis with acupuncture plus moving cupping. Journal of Acupuncture and Tuina Science. 2010; 8: 93-95.

[40] Zhang CQ, Liang TJ, Zhang W. Effects of drug cupping therapy on immune function in chronic asthmatic bronchitis patients during protracted period. Zhongguo Zhong Xi Yi Jie He Za Zhi. 2006; 26: 984-7.

[41] Mohammad Zarei M, Hejazi S, Javadi SA, Farahani H. The efficacy of wet cupping in the treatment of hypertension. ARYA Atherosclerosis Journal 2012, 8: 1-6.

[42] Simons RJ. Cupping. Br Med J. 1924; 1: 38.

[43] Shekarforoush S, Foadoddini M. Cardiac effects of cupping: myocardial infarction, arrhythmias, heart rate and mean arterial blood pressure in the rat heart. Chin J Physiol. 2012; 55: 253-8.

[44] Awad SS. Repigmentation of poliosis after epithelial grafting for vitiligo. Dermatol Surg. 2013; 39: 406-11.

[45] Parveen R. Clinical efficacy of Hijamat Bil Shurt (Wet Cupping) in the management of Ehtebas Tams Sanwi (Secondary Amenorrhoea). Thesis:

[46] Lee MS, Choi TY, Shin BC, Han CH, Ernst E. Cupping for stroke rehabilitation: a systematic review. J Neurol Sci. 2010; 15; 294:70-3.

[47] Lee HJ, Park NH, Yun HJ, Kim S, Jo DY. Cupping therapyinduced iron deficiency anemia in a healthy man. Am J Med. 2008; 121: 5-6.

[48] El-Domyati M, Saleh F, Barakat M and Mohamed N. Evaluation of Cupping Therapy in Some Dermatoses. Egyptian Dermatology Online Journal. 2013; 9: 79-82.

[49] McCarthy GM, Crowe J, McCarthy CJ, Eustace S, Kenny D. Hereditary hemochromatosis: a common, often unrecognized, genetic disease. Cleve Clin J Med. 2002; 69: 224-6.

[50] Marx JJ, Kartikasari AE, Georgiou NA. Can iron chelators influence the progression of atherosclerosis? Hemoglobin. 2008; 32: $123-34$.

[51] McMahon M, Hahn BH. Atherosclerosis and systemic lupus erythematosus: mechanistic basis of the association. Curr Opin Immunol. 2007; 19: 633-9.

[52] Marks SD, Tullus K. Autoantibodies in systemic lupus erythematosus. Pediatr Nephrol. 2012; 27: 1855-68.

[53] Cooper NR, Nemerow GR. The role of antibody and complement in the control of viral infections. J Invest Dermatol. 1984;83(1 Suppl):121s-127s.

[54] Feldman C, Anderson R. Bacteraemic pneumococcal pneumonia: current therapeutic options. Drugs. 2011;71:131-53.

[55] Kidd BL, Urban LA. Mechanisms of inflammatory pain. Br J Anaesth. 2001; 87: 3-11.

[56] Hassanali SH, Oyoo GO. Osteoarthritis: A look at pathophysiology and approach to new treatments: EAOJ. 2011; 5 1-7.

[57] Mutoh T, Kuriyama M. Screening methods for the diagnosis of lysosomal storage disease. Nihon Rinsho. 1995; 53: 2933-7.

[58] Xita N, Tsatsoulis A. Review: fetal programming of polycystic ovary syndrome by androgen excess: evidence from experimental, clinical, and genetic association studies. J Clin Endocrinol Metab. 2006; 91: 1660-6.

[59] McCrindle BW, Urbina EM, Dennison BA, Jacobson MS Steinberger J, Rocchini AP, et al. Drug therapy of high-risk lipid abnormalities in children and adolescents: a scientific statement from the American Heart Association Atherosclerosis, Hypertension, and Obesity in Youth Committee, Council of Cardiovascular Disease in the Young, with the Council on Cardiovascular Nursing. Circulation. 2007; 115: 1948-67.

[60] BANKOLE A. JOHNSON UPDATE ON NEUROPHARMACOLOGICAL TREATMENTS FOR ALCOHOLISM: SCIENTIFIC BASIS AND CLINICAL FINDINGS. Biochem Pharmacol. Biochem Pharmacol. 2008 January 1; 75:34-56.

[61] Lima IV, Bastos LF, Limborço-Filho M, Fiebich BL, de Oliveira AC. Role of prostaglandins in neuroinflammatory and neurodegenerative diseases. Mediators Inflamm. 2012;2012: 946813.

[62] Hirschhaeuser F, Sattler UG, Mueller-Klieser W. Lactate: a metabolic key player in cancer. Cancer Res. 2011; 71: 6921-5.

[63] Walenta S, Mueller-Klieser WF. Lactate: mirror and motor of tumor malignancy. Semin Radiat Oncol, 2004; 14: 267-274.
[64] El Sayed SM, El-Magd RM, Shishido Y, Chung SP, Diem TH, Sakai T, et al. 3-Bromopyruvate antagonizes effects of lactate and pyruvate, synergizes with citrate and exerts novel anti-glioma effects. J Bioenerg Biomembr. 2012; 44: 61-79.

[65] El Sayed SM, El-Magd RM, Shishido Y, Yorita K, Chung SP, Tran DH, et al. D-Amino acid oxidase-induced oxidative stress, 3bromopyruvate and citrate inhibit angiogenesis, exhibiting potent anticancer effects. J Bioenerg Biomembr. 2012; 44: 513-23.

[66] El Sayed SM, Abou El-Magd RM, Shishido Y, Chung SP, Sakai T, Watanabe $\mathrm{H}$, et al. D-amino acid oxidase gene therapy sensitizes glioma cells to the antiglycolytic effect of 3-bromopyruvate. Cancer Gene Ther. 2012; 19: 1-18.

[67] Nakano A, Tsuji D, Miki H, Cui Q, El Sayed SM, Ikegame A, et al. Glycolysis inhibition inactivates ABC transporters to restore drug sensitivity in malignant cells. PLoS One. 2011;6(11):e27222.

[68] El Sayed SM, Mahmoud AA, El Sawy SA, Abdelaal EA, Fouad AM, Yousif RS, et al. Warburg effect increases steady-state ROS condition in cancer cells through decreasing their antioxidant capacities (Anticancer effects of 3-bromopyruvate through antagonizing Warburg effect). Med Hypotheses. 2013; In press.

[69] Ferretti S, Allegrini PR, Becquet MM, McSheehy PM.Tumor interstitial fluid pressure as an early-response marker for anticancer therapeutics. Neoplasia. 2009; 11: 874-81.

[70] Shami PJ, Sauls DL, Weinberg JB. Schedule and concentrationdependent induction of apoptosis in leukemia cells by nitric oxide. Leukemia. 1998; 12: 1461-6.

[71] Mouradian MS, Majumdar SR, Senthilselvan A, Khan K, Shuaib A. How well are hypertension, hyperlipidemia, diabetes, and smoking managed after a stroke or transient ischemic attack? Stroke. 2002; 33: 1656-9.

[72] Sher K, Shah S, Kumar S. Etiologic patterns of ischaemic stroke in young adults. J Coll Physicians Surg Pak. 2013;23: 472-5.

[73] Lee MS, Choi TY, Shin BC, Kim JI, Nam SS. Cupping for hypertension: a systematic review. Clin Exp Hypertens. 2010; 32: 423-5.

[74] Amiri FN, Basirat Z, Omidvar S, Sharbatdaran M, Tilaki KH, Pouramir M. Comparison of the serum iron, ferritin levels and total iron-binding capacity between pregnant women with and without gestational diabetes. J Nat Sci Biol Med. 2013; 4: 302-305.

[75] Sun L, Zong G, Pan A, Ye X, Li H, Yu Z, et al. Elevated plasma ferritin is associated with increased incidence of type 2 diabetes in middle-aged and elderly chinese adults. J Nutr. 2013; 143: 145965.

[76] Bulum T, Duvnjak L. Insulin resistance in patients with type 1 diabetes: relationship with metabolic and inflammatory parameters. Acta Clin Croat. 2013; 52: 43-51.

[77] MANUEL J, REAL F, ARROJA GP, CASTRO A, GARCIABRAGADO F and RICART W: Bloodletting in high-ferritin type 2 diabetes. J. American Diabetes Association. 2001; 51: 10001004.

[78] Hsu YH, Huang MC, Chang HY, Shin SJ, Wahlqvist ML, Chang YL, et al. Association between serum ferritin and microalbuminuria in Type 2 diabetes in Taiwan. Diabet Med. 2013; 30: $1367-73$

[79] Fernández-Real JM, Peñarroja G, Castro A, García-Bragado F, Hernández-Aguado I, Ricart W. Bloodletting in high-ferritin type 2 diabetes: effects on insulin sensitivity and beta-cell function. Diabetes. 2002; 51: 1000-4.

[80] Karasu C. Glycoxidative stress and cardiovascular complications in experimentally-induced diabetes: effects of antioxidant treatment. Open Cardiovasc Med J. 2010; 4: 240-56.

[81] Al-Albani (2007) Sahih and daeef sonan Abo Dawood, Book of medicine. Hadeeth number 3857, Dar Al-Maarif library, Riyadh, Saudi Arabia.

[82] Al-Bukhari MI. The English Translation of Sahih Al Bukhari with the Arabic Text (9 Volume Set). Translated by Muhammad Muhsin Khan, Al-Saadawi Publications, 1996, Book 71, hadeeth 584.

[83] Chakraborty U, Ghosh T. A study on the physical fitness index, heart rate and blood pressure in different phases of lunar month on male human subjects. Int J Biometeorol. 2013; 57: 769-74.

[84] Xu S, Wang L, Cooper E, Zhang M, Manheimer E, Berman B, Shen X, Lao L. Adverse events of acupuncture: a systematic review of case reports. Evid Based Complement Alternat Med. 2013; 2013: 581203.

[85] Weng YM, Hsiao CT. Acquired hemophilia A associated with therapeutic cupping. Am J Emerg Med. 2008 Oct; 26(8): 970.e1-2. 
[86] Masic I. On occasion of 800th anniversary of birth of Ibn al-Nafis-discoverer of cardiac and pulmonary circulation. Med Arh. 2010; 64(5): 309-13.

[87] Shoja MM, Rashidi MR, Tubbs RS, Etemadi J, Abbasnejad F, Agutter PS. Legacy of Avicenna and evidence-based medicine. Int J Cardiol. 2011 Aug 4; 150(3): 243-6.

[88] Rahman SZ, Khan RA, Latif A. Importance of pharmacovigilance in Unani system of medicine. Indian J Pharmacol. 2008. 40(Suppl 1): S17-20.

[89] Kaadan AN. bone fracture in ibn sina medicine. Pan Arab J Orth Traum 2000; 4(2): 151-156.

[90] Ragab AR, Elkablawy MA, Sheik BY, Baraka HN. Antioxidant and Tissue-Protective Studies on Ajwa Extract: Dates from AlMadinah Al-Monwarah, Saudia Arabia. J Environ Anal Toxicol.

[91] Abdelwahab SI, Sheikh BY, Taha MM, How CW, Abdullah R, Yagoub U, El-Sunousi R, Eid EE. Thymoquinone-loaded nanostructured lipid carriers: preparation, gastroprotection, in vitro toxicity, and pharmacokinetic properties after extravascular administration. Int J Nanomedicine. 2013; 8: 2163-72.

[92] Hekmatpou D, Moeini L, Haji-Nadali S. The effectiveness of wet cupping vs. venesection on arterial $\mathrm{O} 2$ saturation level of cigarette smokers: A randomized controlled clinical trial. Pak J Med Sci. 2013 Nov-Dec; 29(6): 1349-1353.

[93] Han JS. Acupuncture and endorphins. Neurosci Lett. 2004; 361: 258-261.

[94] Tian H, Tian YJ, Wang B, Yang L, Wang YY, Yang JS. Impacts of bleeding and cupping therapy on serum $\mathrm{P}$ substance in patients of postherpetic neuralgia. Zhongguo Zhen Jiu. 2013 Aug; 33(8): 678-81.

[95] Green D, McMahon B, Foiles N, Tian L. Measurement of hemostatic factors in EDTA plasma. Am J Clin Pathol. 2008;130: 811-815.

[96] Hong SH, Wu F, Lu X, Cai Q, Guo Y. Study on the mechanisms of cupping therapy. Zhongguo Zhen Jiu. 2011; 31: 932-4.

[97] Barak O, Treat JR, James WD. Antimicrobial peptides: effectors of innate immunity in the skin. Adv Dermatol. 2005; 21: 357-374.

[98] Bassaneze V, Barauna VG, Lavini-Ramos C, Kalil J, Schettert IT, Miyakawa AA, et al. Shear stress induces nitric oxide-mediated vascular endothelial growth factor production in human adipose tissue mesenchymal stem cells. Stem Cells Dev. 2010; 19: 371-8.

[99] Akbari A, Zadeh SM, Ramezani M, Zadeh SMS. The Effect of Hijama (Cupping) on Oxidative Stress Indexes \& various Blood Factors in Patients Suffering from Diabetes Type II.

[100] Arslan M, Yeşilçam N, Aydin D, Yüksel R, Dane S. Wet cupping therapy restores sympathovagal imbalances in cardiac rhythm. J Altern Complement Med. 2014 Apr; 20(4): 318-21.

[101] Al-Albani (2007) Sahih and daeef sonan Abo Dawood, Book of medicine. Hadeeth number 3863, Dar Al-Maarif library, Riyadh, Saudl Arabia.

[102] Al-Bukhari MI (1996) The English Translation of Sahih Al Bukhari with the Arabic Text (9 Volume Set). Translated by Muhammad Muhsin Khan, Al-Saadawi Publications, Book of medicine, chapter of Al-hijamah for headache and migraine. hadeeth no. 5701.

[103] Al-Albani (2008) Sahih and daeef sonan Ibn Majah. Hadeeth no. 3483. Book of medicine. Dar Al-Maarif library, Riyadh, Saudi Arabia.

[104] Al-Albani (2008) Sahih and daeef sonan Ibn Majah. Hadeeth no. 2163-2164. Book of medicine. Dar Al-Maarif library, Riyadh, Saudi Arabia.

[105] Al-Nasaee AS (2008). Al-sonan Al-kobra (Great sonan). Book of medicine. Chapter of Al-hijamah. Hadeeth no. 7550. Dar AlMaarif library, Riyadh, Saudi Arabia.

[106] Al-Albani (2008) Sahih and daeef sonan Ibn Majah. Book of medicine. Chapter of (which are the days of Al-hijamah?). Hadeeth no. 3486. Dar Al-Maarif library, Riyadh, Saudi Arabia.

[107] Swartz MN, Pasternack MS. Principles and Practice of Infectious Diseases. In: Cellulitis and subcutaneous tissue infections. GL Mandell et al., (6th edn) Elsevier Churchill Livingstone, Philadelphia. 2005. pp 1178-1180.

[108] Messlinger K, Fischer MJ, Lennerz JK. Neuropeptide effects in the trigeminal system: pathophysiology and clinical relevance in migraine. Keio J Med. 2011; 60: 82-89.

[109] Al-Bukhari MI. The English Translation of Sahih Al Bukhari. Book of medicine. Chapter of (Cure is in three). Hadeeth numbers 5680-5681. Assryia library, Sayda, Lebanon 2002.
[110] Bouwstra JA, Honeywell-Nguyen PL, Gooris GS, Ponec M. Structure of the skin barrier and its modulation by vesicular formulations. Prog Lipid Res. 2003 Jan; 42(1): 1-36. Review.

[111] Tsuchiya M, Sato EF, Inoue M, Asada A. Acupuncture enhances generation of nitric oxide and increases local circulation. Anesth Analg. 2007 Feb; 104(2): 301-7.

[112] Schäffer MR, Tantry U, van Wesep RA, Barbul A.Nitric oxide metabolism in wounds. J Surg Res. 1997 Jul 15; 71(1): 25-31.

[113] Kamaratos AV, Tzirogiannis KN, Iraklianou SA, Panoutsopoulos GI, Kanellos IE, Melidonis AI. Manuka honey-impregnated dressings in the treatment of neuropathic diabetic foot ulcers. Int Wound J. 2012 Sep 18.

[114] Al-Waili NS, Salom K, Butler G, Al Ghamdi AA. Honey and microbial infections: a review supporting the use of honey for microbial control. J Med Food. 2011 Oct; 14(10): 1079-96.

[115] Al-Albani (2008) Sahih and daeef sonan Ibn Majah. Book of medicine. Chapter of (which are the days of Al-hijamah?). Hadeeth no. 3487. Dar Al-Maarif library, Riyadh, Saudi Arabia.

[116] Eliza J, Daisy P, Ignacimuthu S, Duraipandiyan V. Antidiabetic and antilipidemic effect of eremanthin from Costus speciosus (Koen.)Sm., in STZ-induced diabetic rats. Chem Biol Interact. 2009; 182: 67-72.

[117] Al-Albani (2008) Sahih and daeef sonan Al-termini. Book of medicine of Prophet Muhammad peace be upon him. Chapter of (What was narrated in Al-hijamah). Hadeeth no. 2051. Dar AlMaarif library, Riyadh, Saudi Arabia.

[118] Adams D, Cheng F, Jou H, Aung S, Yasui Y, Vohra S. The safety of pediatric acupuncture: a systematic review. Pediatrics. 2011 Dec; 128(6): e1575-87.

[119] Zhao ZQ. Neural mechanism underlying acupuncture analgesia. Prog Neurobiol. 2008 Aug; 85(4): 355-75.

[120] Ceccherelli F, Rigoni MT, Gagliardi G, Ruzzante L. Comparison of superfi cial and deep acupuncture in the treatment of lumbar myofascial pain: a double-blind ran- domized controlled study. Clin J Pain 2002; 18: 149-53.

[121] Johnstone PA, Polston GR, Niemtzow RC, Martin PJ. Integration of acupuncture into the oncology clinic. Palliat Med 2002; 16: 235-9.

[122] Bullock ML, Kiresuk TJ, Sherman RE, Lenz SK, Culliton PD, Boucher TA, et al. A large randomized placebo-controlled study of auricular acupuncture for alcohol dependence. J Subst Abuse Treat 2002; 22: 71-7.

[123] Dong H, Ludicke F, Comte I, Campana A, Graff P, Bischof P. An exploratory pilot study of acupuncture on the quality of life and reproductive hormone secretion in menopausal women. J Altern Complement Med 2001; 7: 651-8.

[124] Loyeung BY, Cobbin DM. Investigating the effects of three needling parameters (manipulation, retention time, and insertion site) on needling sensation and pain profiles: a study of eight deep needling interventions. Evid Based Complement Alternat Med. 2013; 2013: 136763.

[125] Ernst E. Acupuncture--a critical analysis. J Intern Med. 2006 Feb; 259(2): 125-37.

[126] Madsen MV, Gøtzsche PC, Hróbjartsson A. Acupuncture treatment for pain: systematic review of randomised clinical trials with acupuncture, placebo acupuncture, and no acupuncture groups. BMJ. 2009 Jan 27; 338: a3115.

[127] Lee MS, Ernst E. Acupuncture for pain: an overview of Cochrane reviews. Chin J Integr Med. 2011 Mar; 17(3): 187-9.

[128] Hsiang-Tung C. Neurophysiological basis of acupuncture analgesia. Sci Sin. 1978 Nov-Dec; 21(6): 829-46.

[129] Williams WF (2013). Encyclopedia of Pseudoscience: From Alien Abductions to Zone Therapy. Routledge. p. 3.

[130] Ulett GA (2002). "Acupuncture". In Shermer, M. The Skeptic: Encyclopedia of Pseudoscience. ABC-CLIO. pp. 283-91.

[131] Cao X. Scientific bases of acupuncture analgesia. Acupunct Electrother Res. 2002; 27(1): 1-14.

[132] Chung A, Bui L, Mills E. Adverse effects of acupuncture. Which are clinically significant? Can Fam Physician. 2003 Aug; 49: 9859.

[133] Hicks A. The acupuncture handbook: how acupuncture works and how it can help you. Piatkus Books, 2005, p. 41.

[134] Collinge WJ. (1996). The American Holistic Health Association Complete guide to alternative medicine. New York: Warner Books.

[135] Taylor P, Pezzullo L, Grant SJ, Bensoussan A. (2013). "Costeffectiveness of Acupuncture for Chronic Nonspecific Low Back 
Pain". Pain Practice: The Official Journal of World Institute of Pain.

[136] Drivdahl CE, Miser WF. The use of alternative health care by a family practice population. J Am Board Fam Pract 1998; 11: 1939.

[137] Verhoef MJ, Sutherland LR. General practitioners' assessment of and interest in alternative medicine in Canada. Soc Sci Med 1995; 41: 511-5.

[138] Zaza C, Sellick SM, Willan A, Reyno L, Browman GP. Health care profession- als' familiarity with non-pharmacological strategies for managing cancer pain. Psychooncology 1999;8:99111.
[139] Lao L, Bergman S, Hamilton GR, Langenberg P, Berman B. Evaluation of acupuncture for pain control after oral surgery: a placebo-controlled trial. Arch Otolaryngol Head Neck Surg 1999; 125: 567-72.

[140] Wang B, Tang J, White PF, Naruse R, Sloninsky A, Kariger R, et al. Effect of the intensity of transcutaneous acupoint electrical stimulation on the postoperative analgesic requirement. Anesth Analg 1997; 85: 406-13.

[141] British Medical Acupuncture Society. Warrington, UK. Available at: http:// www.medical-acupuncture.co.uk/about.shtml. Accessed 2003 May 28. 